Análise da Criatividade no Cenário Escolar e sua Expressão em Práticas Inovadoras

Telma de Jesus Reis

Brasília - DF

Agosto de 2016 


\title{
Análise da Criatividade no Cenário Escolar e sua Expressão em Práticas
} Inovadoras

\author{
Telma de Jesus Reis
}

Relatório de Pesquisa apresentado à Assessoria de Pesquisa e Extensão, para a modalidade de Programa Institucional de Bolsas de Iniciação Científica - PIBIC, do Centro Universitário de Brasília - UniCeub. Professor(a) - orientador(a): Draciana de Oliveira Campolina 


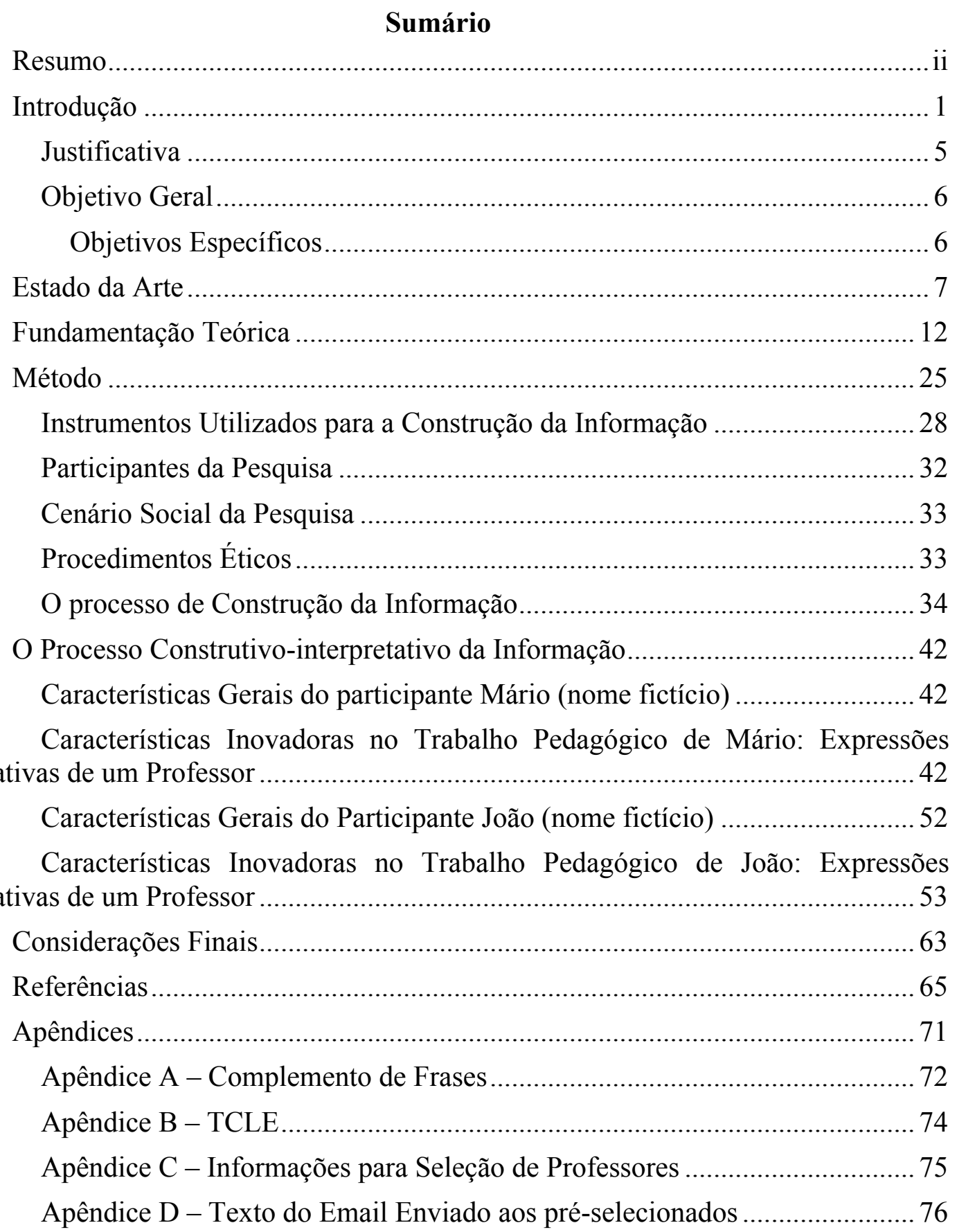




\section{Resumo}

Esta pesquisa faz parte do campo de estudo da psicologia e teve por objetivo investigar as características consideradas criativas dos professores que desenvolvem práticas inovadoras em uma instituição de ensino de nível superior. Esta investigação assumiu como perspectiva teórica a Teoria da Subjetividade proposta por González Rey, na qual a pessoa é compreendida como um ser histórico com desenvolvimento social e como sujeito ativo capaz de promover mudanças no contexto em que atua. A pesquisa foi desenvolvida a partir da Epistemologia Qualitativa, que por seus princípios metodológicos permitem a investigação das características do professor no contexto educacional, construindo indicadores e hipóteses acerca da subjetividade destes profissionais. Os instrumentos utilizados foram a observação das práticas inovadoras e a dinâmica conversacional. $\mathrm{O}$ modelo teórico se embasou em uma construção hipotética, na qual consideramos que a atuação pedagógica dos professores se constitui a partir de dois principais indicadores comuns aos dois participantes da pesquisa, sendo a versatilidade dos recursos pedagógicos e a postura intencional e deliberada em relação a sua produção pedagógica em favor do aprendizado dos alunos. Concluímos destacando a importância dos recursos pedagógicos inovadores, quando são pensados dentro e para o contexto escolar, a partir de um processo dialógico entre o professor-aluno, momentos em que ocorrem trocas e negociações que produzem nos envolvidos uma postura criativa, ativa e reflexiva. Ressaltamos, também, a relevância da emocionalidade no contexto educacional, a qual não está relacionada com a materialização dos recursos pedagógicos em si, mas sim com a produção subjetiva do professor.

Palavras-Chave: Professores. Subjetividade. Criatividade. Práticas Inovadoras. Nível Superior. 
Não haveria cultura nem história sem inovação, sem criatividade, sem curiosidade, sem liberdade sendo exercida ou sem liberdade pela qual, sendo negada, se luta (Freire, 2000, p.30).

\section{Introdução}

Esta pesquisa deu enfoque a figura do professor enquanto um agente promotor de práticas inovadoras atuando de forma criativa no ambiente educacional de nível superior. $\mathrm{O}$ tema proposto foi elaborado com base na psicologia, sendo esta a norteadora da construção deste conhecimento. Dentro dessa ciência este estudo foi baseado pela perspectiva da psicologia histórico-cultural, com ênfase na construção teórica de González Rey.

A Psicologia Histórico-cultural tem como um dos principais autores Vigotsky, e embora ele não tenha sido o único, foi de grande importância para o surgimento dessa abordadagem. De acordo com González Rey (2007) Vigotsky foi um teórico que problematizou, em alguns momentos da sua obra, a importância do sentido produzido pela pessoa, que em sua teoria era composto por um desdobramento do cognitivo e do afetivo, e foi partindo desse pressuposto que González Rey aprofundou os seus estudos no tema e produziu a categoria sentido subjetivo que compreende a produção individual do homem que se constitui pelo simbólico e emocional.

Nesta pesquisa os participantes foram compreendidos a partir da teoria históricocultural da subjetividade. Para esta teoria a pessoa é vista como "um homem constituído subjetivamente em sua própria história, em que o sentido aparece como registro emocional comprometido com os significados e as necessidades que vão desenvolvendo-se no decorrer de sua história” (González Rey, 2005b, p. 235).

Segundo Campolina e Martínez (2013) a teoria histórico-cultural da subjetividade proposta por Gonzalez Rey auxilia no entendimento da complexa produção humana, onde se compreende que a realidade deve ser vista a partir da forma pela qual as pessoas a 
subjetivam. Neste pressuposto, o que interessa a esta teoria é o conjunto de elementos que a pessoa produz, com ênfase na ligação entre os significados e os sentidos relacionados ao espaço de ação das pessoas e do coletivo.

A Teoria da Subjetividade foi escolhida para dar suporte ao entendimento do fenômeno estudado pela compreensão de que a mesma se desenvolve atendendo aos pressupostos do homem considerado pós-moderno. Trata-se de uma abordagem atual que atende a percepção que acreditamos, de que a pessoa está em constante processo de transformação, modificando o mundo e sendo modificado por ele, processo esse denominado recursividade.

A construção desse trabalho se apóia no conceito de subjetividade de González Rey (2011), descrito na Teoria da Subjetividade, em que:

A subjetividade, nesta aproximação, é definida não apenas como organização intrapsíquica individual, mas como produção diferenciada e simultânea de sentidos subjetivos em dois níveis estreitamente relacionados entre si: o individual e o social. Como pensado por autores como Vygotsky e Rubinstein, o social se torna relevante para o desenvolvimento psíquico só se considerando através da posição ativa da pessoa nos diferentes espaços em que atua, o que pressupõe a presença de sua história de vida em termos de suas configurações subjetivas atuais (González Rey, 2011, p. 30).

O entendimento da história de vida da pessoa não está em observar os acontecimentos objetivos da sua vida, mas sim na produção de configurações subjetivas expressas no momento atual da vida da pessoa.

É esta visão da pessoa como ser capaz de produzir mudanças que auxilia na compreensão da inovação e criatividade no ambiente educacional. Pois é neste contexto, que surgem as ações e interações das pessoas que atuam de forma ativa no espaço educacional (Campolina e Martínez, 2013).

Essa produção de mudanças no contexto educacional, no qual Carbolnell (2002) conceitua como inovação educativa ou renovação pedagógica trata-se de "um conjunto de 
ideias, processos e estratégias, mas ou menos sistematizadas, através dos quais se trata de introduzir e provocar mudanças na prática educativa vigente" (Carbolnell,2002, p.11). Para o autor, a inovação educativa tem um caráter ideológico, cognitivo, ético e afetivo, onde se manifestam a subjetividade da pessoa e respectivamente o seu desenvolvimento individual.

Nessa perspectiva das práticas educativas inovadoras, como definida acima por Carbonell, surge a figura do professor que pode se posicionar como uma pessoa criativa em sua atuação pedagógica. O conceito de criatividade desenvolvido nesse trabalho relaciona-se a proposta trazida por Arruda (2014), em que a mesma descreve que:

O trabalho pedagógico criativo contempla, além do ensino, a expressão da criatividade na dinâmica mais ampla dos processos educativos, abrange os diferentes participantes do contexto escolar, as relações entre eles, as ações e atividades que visam aos processos de aprendizagem e desenvolvimento dos estudantes, como o planejamento e a formação docente (2014, p. 23).

Após uma breve definição de criatividade e inovação, vamos aprofundarnos um pouco mais sobre a compreensão do conceito de inovação educativa, no qual de acordo com Carbonell (2002) é um fenômeno processual, que se compreende pela contemplação da vida nas aulas, sendo a forma como a escola se organiza, o funcionamento da comunidade educativa e também a cultura profissional dos professores. Nesta pesquisa foi intenção compreender o fenômeno relacionado à cultura profissional dos professores,em relação a como os mesmos subjetivam as suas práticas pedagógicas consideradas criativas.

Para compreensão de fenômeno utilizamos o Método Construtivo-interpretativo, baseado na Epistemologia Qualtitativa proposto por González Rey (2002), sendo enfatizado que a produção do conhecimento na pesquisa qualitativa não ocorre de maneira rígida e linear, mas segundo a sua proposta ela acontece a partir de um processo considerado complexo que combina produção teórica e empírica. Conforme o autor, a pesquisa qualitativa está vinculada a produção de ideias e o desenvolvimento da teoria, e para que estas aconteçam é preciso o pensar do pesquisador. 
A Epistemologia Qualitativa, proposta por González Rey, está baseada na Teoria da Subjetividade e nesta "articula-se ás categorias sujeito, subjetividade individual, subjetividade social, sentido subjetivo e configuração subjetiva, formando um conjunto entrelaçado de categorias não reificadas que se organizam e se articulam dinamicamente nas expressões da subjetividade" (Rossato, Martins e Martínez, 2014, p. 38).

O objeto deste estudo foi constituído pela análise das características criativas encontradas nosprofessores, em seu trabalho pedagógico. As características encontradas foram comparadas ao consenso existente entre os autores que pesquisam sobre criatividade e inovação educativa.

Ainda nesse contexto, três autores foram usados como referencias para a produção e interpretação da informção. Utilizamos um conjunto de características citadas por Carbonell (2002), como sendo definidoras de um professor inovador: Ser pautado na ética e ideologia; Ser ativo; Ser autônomo e crítico; Assumir dúvidas mas ter sempre entusiasmo; Transformar dificuldades em possibilidades; Ser capaz de compreender a necessidade de novos conhecimentos e as formas de aprendizagem; Ser coerente com o que se diz e o que se faz; Ser alguém que atua pensando e pensa atuando; Ser apaixonado pelo conhecimento; E ser realista.

Também subsidiou nosso processo de construção da informação o conceito de Campolina e Martínez (2011), em que ambas enfatizam que a proposta de inovação deve partir de princípios como esforço deliberado e intencionalmente assumidos; práticas pedagógicas criativas permeadas pela insistência. As autoras corroboram com a visão de Carbonell (2002), considerando o pensamento vinculado à ação da pessoa que se propõe a promover práticas inovadoras. 


\section{Justificativa}

A educação é um tema de interesse para diversas áreas das ciências e a Psicologia surge neste cenário buscando dentre outras ações e conhecimentos a construção e ressignificação das práticas pedagógicas no ambiente educacional. Diante deste pressuposto, considera-se que a psicologia contribui com estudos científicos que proporcionam conhecimento e enriquecem o entendimento desta grande área que é a educação.

O ensino educacional, no âmbito institucional, compreende diversos momentos, sendo em uma distinção básica os níveis fundamental, médio e superior. O foco desse trabalho foi em uma instituição de nível superior, sendo esse visto como um momento diferenciado dos anteriores, pois é um ambiente que exige um processo pedagógico mais ativo, dinâmico e autônomo, influenciando todo os atores envolvido nesse contexto.

Os professores da educação de nível superior que atuam com práticas inovadoras, são profissionais que tendem a modificar o cenário educacional e buscam promover novas formas de aprendizado. Esses profissionais aspiram romper com o modelo tradicional de ensino e se propõe a um novo modelo de intervenção educacional que proporcione um melhor aprendizado para os respectivos alunos.

O objeto de estudo foi interpretar as características consideradas criativas, encontradas nos professores de nível superior em sua prática pedagógica inovadora. A criatividade dos professores, foi compreendida a partir da forma como o professor subjetiva sua capacidade criativa na prática profissional.

Martínez (2014) destaca que "entende-se, por criatividade, uma forma de expressão da subjetividade, que se manifesta na produção de novidade em diferentes níveis e formas, em função da emergência de sentidos subjetivos e configurações subjetivas diversas, assim como da condição de sujeito da ação" (Martínez, 1997, 2000, 2001, 2004, 2006, 2009; apud Martínez, 2014, p.71). 
A partir das construções teóricas sobre a relação criatividade e inovação no ensino superior,é possível uma ampliação do conhecimento sobre o tema, permitindo o surgimento de novas formas de inteligibilidade sobre a criatividade educacional, uma vez que trata-se de uma discussão atual e em processo de produção.

O intuito dessa pesquisa não foi de padronizar o perfil do professor criativo, mas sim de contribuir com o avanço do conhecimento sobre criatividade no contexto da inovação educacional, gerando assim mais uma ferramenta de apoio ao cenário pedagógico.

O compromisso social dessa pesquisa foi o de contribuir para ampliação do conhecimento de expressões da criatividade e inovação no contexto da educação de nível superior, buscando dar visibilidade ao complexo fenômeno que aqui denominamos como práticas pedagógicas inovadoras.

\section{Objetivo Geral}

O objetivo geral foi: Investigar como o professor subjetiva a sua criatividade, no trabalho pedagógico, referente a prática educativa inovadora.

\section{Objetivos Específicos}

Os objetivos específicos foram:

1) Compreender a partir das ações e expressões referentes a prática pedagógicainovadora, quais as significações subjetivas que os professores produzem acerca de si mesmos no desempenho das suas práticas criativas.

2) Discutir a produção de sentidos sobre os resultados vivenciados pela implementação e desempenho das práticas educativas inovadoras. 


\section{Estado da Arte}

Nessa etapa o objetivo foi obter um aprofundamento sobre o tema da pesquisa, através de informações cientificas trazidas por outros autores. Para a sua produção foram utilizados cinco circunscritores, sendo: criatividade, profesor, inovação educativa, práticas inovadoras e educação superior. As combinações usados foram: criatividade e educação superior; criatividade e professor; professor e inovação educativa; e profesor e práticas inovadoras. Todas as pesquisas foram realizadas na base de dados da Scielo e ocorreram nos meses de dezembro de 2015 e janeiro de 2016.

O recorte temporal foi do ano de 2005 ao ano de 2015. Inicialmente pensamos em um período temporal menor, no entanto, a escassez de pesquisas, com ênfase no que estávamos abordando, nos fez contemplar um maior tempo. A partir dessa definição temporal foram encontrados 16 achados, no entanto, ressalvamos que houve um número maior, mas muitas pesquisas relacionavam diretamente a inovação com aspectos estritamente tecnológicos, o que nos levou a não considerá-las como semelhantes ao que propusemos abordar.

Abaixo segue o descritivo (Figura 1) dos 16 achados, cotendo informações sobre o título, o resumo, a categoria, o tipo e a referência /ano. Em relação a categoria, 13 tratam-se de pesquisas qualitativas e três são pesquisas quantitativas; quanto ao tipo, todas foram de formato artigo. No que se refere ao objeto de estudo, 11 pesquisas se relacionaram diretamente a figura do professor e quatro achados envolviam outros elementos da educação, sendo: uma com foco na perspectiva do aluno; uma com foco na percepção dos coordenadores sobre a prática discente; uma sobre o olhar do gestor em relação a prática discente; e a última em relação ao contexto educacional. 


\begin{tabular}{|c|c|c|c|}
\hline Título & Resumo/Abstract & \begin{tabular}{|c|} 
Categoria/ \\
Tipo
\end{tabular} & $\begin{array}{c}\text { Referência / } \\
\text { Ano }\end{array}$ \\
\hline $\begin{array}{l}\text { Criatividade } \\
\text { em programas } \\
\text { de pós- } \\
\text { graduação em } \\
\text { educação: } \\
\text { práticas } \\
\text { pedagógicas e } \\
\text { fatores } \\
\text { inibidores }\end{array}$ & $\begin{array}{l}\text { Este estudo investigou procedimentos pedagógicos que favorecem o } \\
\text { desenvolvimento e expressão da criatividade discente, utilizados por } \\
\text { professores de programas de pós-graduação em educação e fatores que } \\
\text { dificultam promover tal expressão. Foram entrevistados } 15 \text { professores de } \\
\text { universidades públicas, sendo os dados submetidos à análise de conteúdo. Os } \\
\text { resultados indicaram distintas práticas pedagógicas utilizadas pelos docentes } \\
\text { favorecedoras da criatividade dos estudantes, sendo instigar o aluno por meio } \\
\text { de desafios e questionamentos a mais frequente. [...] }\end{array}$ & $\begin{array}{l}\text { Quant. } \\
\text { Artigo }\end{array}$ & $\begin{array}{l}\text { LIMA, } \\
\text { Vivianne } \\
\text { Bezerra } \\
\text { Figueiredo; } \\
\text { ALENCAR, } \\
\text { Eunice M. L. } \\
\text { Soriano de. } \\
2014 .\end{array}$ \\
\hline \begin{tabular}{ll}
\multicolumn{2}{l}{ Criatividade } \\
na formação e \\
atuação & do \\
professor & do \\
curso & de \\
Letras &
\end{tabular} & $\begin{array}{l}\text { A pesquisa investigou como a criatividade era tratada na formação e atuação } \\
\text { do professor do Curso de Letras. Foram entrevistados } 20 \text { professores de duas } \\
\text { instituições de educação superior [...]. Os resultados indicaram que os } \\
\text { professores atribuem importância à criatividade no mundo atual; acreditam } \\
\text { no potencial criativo de seus alunos; têm noção sobre criatividade, embora } \\
\text { com dificuldade para defini-la; valem-se de vários procedimentos } \\
\text { pedagógicos que a facilitam, embora não os utilizem de forma intencional; } \\
\text { [...] }\end{array}$ & $\begin{array}{l}\text { Qual. } \\
\text { Artigo }\end{array}$ & $\begin{array}{l}\text { OLIVEIRA, } \\
\text { Zélia Maria } \\
\text { Freire de \& } \\
\text { ALENCAR, } \\
\text { Eunice Maria } \\
\text { Lima Soriano } \\
\text { de. } 2007 .\end{array}$ \\
\hline $\begin{array}{l}\text { Criatividade } \\
\text { na educação } \\
\text { superior: } \\
\text { fatores } \\
\text { inibidores }\end{array}$ & $\begin{array}{l}\text { O objetivo deste estudo foi investigar elementos percebidos por professores } \\
\text { da educação superior como inibidores à promoção de condições adequadas } \\
\text { ao desenvolvimento e expressão da criatividade de seus alunos. Trezentos e } \\
\text { trinta e oito professores de instituições públicas e particulares de ensino } \\
\text { superior responderam a uma checklist de barreiras à promoção de condições } \\
\text { favoráveis à criatividade em sala de aula. Alunos com dificuldades de } \\
\text { aprendizagem em sala de aula, desinteresse do aluno pelo conteúdo } \\
\text { ministrado, poucas oportunidades para discutir e trocar ideias com colegas de } \\
\text { trabalho sobre estratégias instrucionais e elevado número de alunos em sala } \\
\text { de aula foram os itens com maior percentual de respostas.[...] }\end{array}$ & $\begin{array}{l}\text { Quant. } \\
\text { Artigo }\end{array}$ & $\begin{array}{l}\text { ALENCAR, } \\
\text { Eunice Maria } \\
\text { Lima Soriano } \\
\text { de; FLEITH, } \\
\text { Denise de } \\
\text { Souza. 2010. }\end{array}$ \\
\hline $\begin{array}{l}\text { Criatividade } \\
\text { no Ensino } \\
\text { Fundamental: } \\
\text { Fatores } \\
\text { Inibidores e } \\
\text { Facilitadores } \\
\text { segundo } \\
\text { Gestores } \\
\text { Educacionais } \\
1 \mathrm{E}\end{array}$ & $\begin{array}{l}\text { Este estudo investigou a percepção de gestores de instituições de ensino } \\
\text { fundamental sobre fatores que dificultam o professor promover o } \\
\text { desenvolvimento da criatividade discente e procedimentos que poderiam } \\
\text { utilizar para apoiar o professor na promoção da criatividade em sala de aula. } \\
\text { Participaram } 118 \text { gestores de escolas públicas e particulares, os quais } \\
\text { responderam a uma checklist de barreiras à criatividade em sala de aula e } \\
\text { quatro questões abertas. Fatores inibidores mais apontados foram: } \\
\text { desconhecimento pelo professor de práticas pedagógicas que poderiam ser } \\
\text { utilizadas para propiciar o desenvolvimento da criatividade dos alunos e falta } \\
\text { de entusiasmo pela atividade docente. [...] }\end{array}$ & $\begin{array}{l}\text { Quant. } \\
\text { Artigo }\end{array}$ & $\begin{array}{l}\text { ALENCAR, } \\
\text { Eunice M. L. } \\
\text { Soriano de; } \\
\text { FLEITH, } \\
\text { Denise de } \\
\text { Souza; } \\
\text { BORUCHOV } \\
\text { ITCH, } \\
\text { Evely and B } \\
\text { ORGES, } \\
\text { Clarissa } \\
\text { Nogueira. } 201 \\
\text { 5. } \\
\end{array}$ \\
\hline $\begin{array}{l}\text { Criatividade } \\
\text { no trabalho } \\
\text { docente } \\
\text { segundo } \\
\text { professores } \\
\text { de história: } \\
\text { limites e } \\
\text { possibilidades }\end{array}$ & $\begin{array}{l}\text { Foi objetivo do presente estudo investigar componentes da organização do } \\
\text { trabalho pedagógico e elementos de caráter pessoal/individual que agem } \\
\text { como inibidores e facilitadores da expressão da criatividade do professor de } \\
\text { História. Participaram do estudo } 16 \text { professores de História de } 5^{\mathrm{a}} \text { a } 8^{\mathrm{a}} \text { séries } \\
\text { do Ensino Fundamental de cinco escolas públicas e cinco escolas particulares } \\
\text { [...]. Vários aspectos foram identificados como estímulos e limites à } \\
\text { criatividade no trabalho docente. Liberdade e a paixão pelo trabalho foram os } \\
\text { facilitadores mais enfatizados. Problemas no relacionamento professor-aluno } \\
\text { foi um dos limites mais destacado. Este estudo contribui para desvelar } \\
\text { aspectos que impedem a expressão criativa do professor e outros relativos a } \\
\text { um ambiente pedagógico favorável à criatividade docente. }\end{array}$ & $\begin{array}{l}\text { Qual. } \\
\text { Artigo }\end{array}$ & $\begin{array}{l}\text { MARIANI, } \\
\text { Maria de } \\
\text { Fátima } \\
\text { Magalhães; } \\
\text { ALENCAR, } \\
\text { Eunice Maria } \\
\text { Lima Soriano } \\
\text { de. } 2005 \text {. }\end{array}$ \\
\hline
\end{tabular}




\begin{tabular}{|c|c|c|c|}
\hline $\begin{array}{l}\text { Manifestações } \\
\text { da criatividade } \\
\text { no trabalho } \\
\text { pedagógico do } \\
\text { professor de } \\
\text { artes visuais }\end{array}$ & $\begin{array}{l}\text { A criatividade é um tema presente no ensino de arte, tanto por sua estreita } \\
\text { relação com a arte quanto pelas exigências sociais e políticas que interferem } \\
\text { no contexto escolar e impõem-na como essencial para a ação pedagógica. } \\
\text { Com o objetivo de explicitar as manifestações da criatividade no trabalho do } \\
\text { professor de artes visuais, realizamos observação, entrevistas, análise } \\
\text { documental e registros imagéticos em duas escolas estaduais. A partir de uma } \\
\text { análise qualitativa, definimos os seguintes eixos temáticos: Clima criativo no } \\
\text { contexto escolar; Iconografia da criatividade no contexto escolar; A } \\
\text { criatividade como objetivo e a arte como estratégia; A criatividade no } \\
\text { trabalho pedagógico para o aluno com deficiência. Concluímos que as } \\
\text { manifestações da criatividade apresentam dilemas que oscilam entre os } \\
\text { aspectos de sua expressão - naturalizados e cristalizados no trabalho } \\
\text { pedagógico - e as expectativas dos professores de artes visuais, que buscam } \\
\text { condições para a expressão e o desenvolvimento da criatividade no contexto } \\
\text { escolar. }\end{array}$ & $\begin{array}{l}\text { Qual. } \\
\text { Artigo }\end{array}$ & $\begin{array}{l}\text { ANACHE, } \\
\text { Alexandra } \\
\text { Ayach; } \\
\text { FERNANDE } \\
\text { S, Vera Lúcia } \\
\text { Penzo. } 2015 .\end{array}$ \\
\hline $\begin{array}{l}\text { Investigando } \\
\text { a criatividade } \\
\text { junto a } \\
\text { professores: } \\
\text { pesquisas } \\
\text { brasileiras }\end{array}$ & $\begin{array}{l}\text { [...] este trabalho teve como objetivo identificar pesquisas brasileiras sobre } \\
\text { criatividade realizadas com amostra de professores a fim de verificar o que } \\
\text { tem sido estudado e os resultados que vêm sendo obtidos, visando traçar um } \\
\text { quadro do que já se conhece acerca do fenômeno da criatividade junto a estes } \\
\text { profissionais. [...] Após seleção das pesquisas, as mesmas foram divididas de } \\
\text { acordo com seu objetivo, de forma que foram agrupadas em relação à } \\
\text { temática: influência da organização escolar sobre a criatividade, contribuição } \\
\text { dos professores neste processo, concepção dos professores sobre a } \\
\text { criatividade, capacidade dos mesmos identificarem a criatividade em seus } \\
\text { alunos, dificuldades e limitações na criação de ambiente criativo, treinamento } \\
\text { de modelos de atuação criativa. O que se verificou é que a influência } \\
\text { exercida pelo professor no processo de desenvolvimento da criatividade na } \\
\text { escola tem sido foco de atenção da maioria das pesquisas brasileiras. A } \\
\text { análise das pesquisas aponta para um professor mal preparado, com grandes } \\
\text { dificuldades para lidar com as diferenças individuais presentes nos alunos, } \\
\text { desconhecedor de estratégias criativas e estimuladoras para ensinar e, ele } \\
\text { próprio, desmotivado frente às condições institucionais que encontra em seu } \\
\text { trabalho. }\end{array}$ & $\begin{array}{l}\text { Qual. } \\
\text { Artigo }\end{array}$ & $\begin{array}{l}\text { NAKANO, } \\
\text { Tatiana de } \\
\text { Cássia. } 2009 .\end{array}$ \\
\hline $\begin{array}{l}\text { Estímulo à } \\
\text { criatividade } \\
\text { por } \\
\text { professores } \\
\text { de } \\
\text { Matemática e } \\
\text { motivação do } \\
\text { aluno }\end{array}$ & $\begin{array}{l}\text { O estudo investigou a percepção de alunos do Ensino Médio quanto à } \\
\text { utilização, por seu professor de Matemática, de práticas docentes favoráveis } \\
\text { ao desenvolvimento da criatividade e motivação em Matemática. } \\
\text { Participaram do estudo } 396 \text { alunos, os quais responderam ao Inventário de } \\
\text { Práticas Docentes para a Criatividade e à Escala de Motivação em } \\
\text { Matemática. Diferenças significativas foram observadas entre alunos de } \\
\text { escola pública e particular na percepção das práticas docentes promotoras da } \\
\text { criatividade, utilizadas por seu professor, e em motivação em Matemática, a } \\
\text { favor dos alunos da escola particular. Observou-se ainda relação significativa } \\
\text { entre a percepção dos alunos quanto ao uso de estratégias em sala de aula } \\
\text { para desenvolver a criatividade por seu professor de Matemática e motivação } \\
\text { do aluno em Matemática, entre motivação em Matemática e rendimento } \\
\text { acadêmico nessa disciplina e entre a percepção pelo aluno de práticas } \\
\text { pedagógicas para a criatividade e seu rendimento em Matemática. }\end{array}$ & $\begin{array}{l}\text { Qual. } \\
\text { Artigo }\end{array}$ & $\begin{array}{l}\text { OTAVIANO, } \\
\text { Alessandra } \\
\text { Barbosa } \\
\text { Nunes; } \\
\text { ALENCAR, } \\
\text { Eunice Maria } \\
\text { Lima Soriano } \\
\text { de; } \\
\text { FUKUDA, } \\
\text { Cláudia } \\
\text { Cristina. 201 } \\
\text { 2. }\end{array}$ \\
\hline $\begin{array}{l}\text { Importância } \\
\text { da } \\
\text { criatividade } \\
\text { na escola e no } \\
\text { trabalho } \\
\text { docente } \\
\text { segundo } \\
\text { coordenadore } \\
\text { s pedagógicos }\end{array}$ & $\begin{array}{l}\text { O objetivo principal desta pesquisa foi examinar a percepção de } \\
\text { coordenadores pedagógicos sobre a importância do } \\
\text { desenvolvimento/expressão da criatividade docente, investigada por meio de } \\
\text { entrevista com } 12 \text { coordenadores pedagógicos do ensino fundamental de } \\
\text { escolas particulares de Brasília, Distrito Federal. As entrevistas foram } \\
\text { gravadas em áudio e posteriormente transcritas, utilizando-se a análise de } \\
\text { conteúdo para análise de dados. Os resultados indicaram que para todos os } \\
\text { coordenadores entrevistados é muito importante a criatividade estar presente } \\
\text { no cotidiano escolar, sobretudo no trabalho docente, devendo o professor ser } \\
\text { criativo principalmente por motivos relacionados ao aluno, sendo destacados } \\
\text { o aumento do interesse e estímulo deste, a atribuição de significado ao } \\
\text { conhecimento, a facilitação da sua aprendizagem, bem como o atendimento } \\
\text { às suas necessidades educativas. }\end{array}$ & $\begin{array}{l}\text { Qual. } \\
\text { Artigo }\end{array}$ & $\begin{array}{l}\text { OLIVEIRA, } \\
\text { Edileusa } \\
\text { Borges Porto; } \\
\text { ALENCAR, } \\
\text { Eunice Maria } \\
\text { Lima Soriano } \\
\text { de. } 2012 .\end{array}$ \\
\hline
\end{tabular}




\begin{tabular}{|c|c|c|c|}
\hline $\begin{array}{l}\text { Criatividade e } \\
\text { escola: } \\
\text { limites e } \\
\text { possibilidades } \\
\text { segundo } \\
\text { gestores e } \\
\text { orientadores } \\
\text { educacionais }\end{array}$ & $\begin{array}{l}\text { Este estudo investigou concepções de criatividade e importância atribuída a } \\
\text { ela por gestores e orientadores educacionais, bem como elementos inibidores } \\
\text { e facilitadores à implementação de práticas pedagógicas para o } \\
\text { desenvolvimento da criatividade e à intervenção desses profissionais no } \\
\text { sentido de promover a criatividade na organização escolar. Nove gestores e } \\
10 \text { orientadores educacionais foram entrevistados, utilizandose análise de } \\
\text { conteúdo para exame dos dados. Constatou-se que, embora esses } \\
\text { profissionais considerassem a criatividade importante, o conhecimento que } \\
\text { embasava sua prática advinha do senso comum. Os elementos inibidores e } \\
\text { facilitadores à implementação de práticas pedagógicas para o } \\
\text { desenvolvimento da criatividade mais destacados foram de natureza } \\
\text { pessoal/pedagógica relacionados ao professor, seguidos dos de natureza } \\
\text { administrativa. Os elementos inibidores à intervenção de gestores e } \\
\text { orientadores educacionais em prol do desenvolvimento da criatividade na } \\
\text { escola mais frequentemente apontados foram referentes ao docente e à } \\
\text { família, ao passo que, entre os facilitadores, houve destaque para os relativos } \\
\text { às suas funções. }\end{array}$ & $\begin{array}{l}\text { Qual. } \\
\text { Artigo }\end{array}$ & $\begin{array}{l}\text { OLIVEIRA, } \\
\text { Eny da Luz } \\
\text { Lacerda; } \\
\text { ALENCAR, } \\
\text { Eunice Maria } \\
\text { Lima Soriano } \\
\text { de. } 2010 \text {. }\end{array}$ \\
\hline $\begin{array}{l}\text { A criatividade } \\
\text { do professor: } \\
\text { a relação } \\
\text { entre o } \\
\text { sentido } \\
\text { subjetivo da } \\
\text { criatividade e } \\
\text { a pedagogia } \\
\text { de projetos }\end{array}$ & $\begin{array}{l}\text { Buscou-se compreender a relação entre o sentido subjetivo da criatividade do } \\
\text { professor e sua prática pedagógica com projetos. Partiu-se da teoria } \\
\text { históricocultural da subjetividade desenvolvida por González Rey (1997, } \\
\text { 1999, 2001, 2002b, 2004). O método adotado foi o estudo de caso com dois } \\
\text { professores que trabalham com projetos de estratégia relativos ao ensino- } \\
\text { aprendizagem em uma mesma escola. Vários instrumentos foram utilizados: } \\
\text { a técnica de completamento de frases, redações, observação direta, análise } \\
\text { documental e, principalmente, a entrevista como processo. Como conclusão } \\
\text { principal, percebeu-se que se trata de uma relação recursiva. Além disso, a } \\
\text { pesquisa demonstrou que os sentidos subjetivos de importantes aspectos } \\
\text { contextuais - como o espaço em sala de aula - são mediadores da relação } \\
\text { colocada sob foco. Por fim, notou-se que conflitos e contradições vividos na } \\
\text { prática com projetos configuram-se como uma situação potencial de } \\
\text { desenvolvimento em relação ao sentido subjetivo da criatividade e à própria } \\
\text { prática docente. }\end{array}$ & $\begin{array}{l}\text { Qual. } \\
\text { Artigo }\end{array}$ & $\begin{array}{l}\text { MOURAO, } \\
\text { Renata } \\
\text { Fernandes; } \\
\text { MARTINEZ, } \\
\text { Albertina } \\
\text { Mitjáns. } 2006 \\
\text {. }\end{array}$ \\
\hline $\begin{array}{l}\text { Educação da } \\
\text { mente e do } \\
\text { corpo, } \\
\text { professor } \\
\text { pesquisador } \\
\text { reflexivo e a } \\
\text { ciência do } \\
\text { concreto }\end{array}$ & $\begin{array}{l}\text { A partir das contribuições de Lovisolo (1995), que usa a imagem do bricoleur } \\
\text { de Lévi-Strauss para pensar a prática docente, tentamos neste artigo } \\
\text { resignificar as contribuições da corrente de formação docente denominada de } \\
\text { Professor Pesquisador Reflexivo (PPR). Seus principais autores, sobretudo, } \\
\text { Stenhouse, é visto sob a perspectiva que domina em sua interpretação e que } \\
\text { enfatiza a autonomia, a criatividade, a arte e posta em contraposição com a } \\
\text { perspectiva delineada por Lovisolo a partir dos entendimentos de Lévi- } \\
\text { Strauss sobre as formas do pensamento primitivo e científico. Por último, são } \\
\text { postas questões sobre o funcionamento do ensino que, o romantismo que } \\
\text { vigora no campo da formação do PPR, parece operar recusando tanto esse } \\
\text { tipo de questões quanto suas possíveis respostas. }\end{array}$ & $\begin{array}{l}\text { Qual. } \\
\text { Artigo }\end{array}$ & $\begin{array}{l}\text { SILVA, Tania } \\
\text { Mara Tavares; } \\
\text { LOVISOLO, } \\
\text { Hugo } \\
\text { Rodolfo. } 201 \\
1 .\end{array}$ \\
\hline $\begin{array}{l}\text { A inovação e } \\
\text { o desinvesti- } \\
\text { mento } \\
\text { pedagógico } \\
\text { na Educação } \\
\text { Física } \\
\text { escolar: uma } \\
\text { leitura a partir } \\
\text { da teoria do } \\
\text { reconheci- } \\
\text { mento social }\end{array}$ & $\begin{array}{l}\text { Este artigo pretende discutir a teoria do reconhecimento social de Axel } \\
\text { Honneth, objetivando explicitar o potencial dessa teoria para melhor } \\
\text { compreender as relações intersubjetivas construídas na cultura escolar e o } \\
\text { processo de construção das identidades dos professores de Educação Física. } \\
\text { A condição de "segunda classe" da Educação Física na escola implica que a } \\
\text { luta por reconhecimento se constitua num elemento fundamental da } \\
\text { construção das identidades dos professores da área, uma vez que o sentido de } \\
\text { "ser" professor de Educação Física tem uma relação estreita com as } \\
\text { condições de reconhecimento da área/disciplina na escola. }\end{array}$ & $\begin{array}{l}\text { Qual. } \\
\text { Artigo }\end{array}$ & $\begin{array}{l}\text { FARIA, } \\
\text { Bruno de } \\
\text { Almeida; } \\
\text { MACHADO, } \\
\text { Thiago da } \\
\text { Silva; } \\
\text { BRACHT, } \\
\text { Valter. } \\
\text { 2012. }\end{array}$ \\
\hline $\begin{array}{l}\text { Rupturas } \\
\text { urgentes em } \\
\text { educação }\end{array}$ & $\begin{array}{l}\text { [...] Inspirando-se em Christensen, o texto discute armadilhas da inovação, } \\
\text { entre elas: pretender inovar sem inovar-se; buscar controlar o processo de } \\
\text { inovação; viver de promessas impossíveis ou de promessas mesquinhas. Os } \\
\text { dados sugerem que nosso sistema educacional é inepto: as crianças não } \\
\text { aprendem, os professores tendem a ser muito mal formados e mal pagos, a } \\
\text { escola está ficando para trás, novas tecnologias não têm chance, e os alunos } \\
\text { reclamam cada vez mais.[...] Referência fundamental é o professor, que, } \\
\text { afinal, é o agente principal da mudança. Mudar o professor é crucial, porque } \\
\text { praticamente todas as mudanças na escola são mudanças docentes. Criticar } \\
\text { apenas não basta (nunca basta). É fundamental garantir novas oportunidades. }\end{array}$ & $\begin{array}{l}\text { Qual. } \\
\text { Artigo }\end{array}$ & $\begin{array}{l}\text { DEMO, } \\
\text { Pedro. } 2010 .\end{array}$ \\
\hline
\end{tabular}




\begin{tabular}{|c|c|c|c|}
\hline $\begin{array}{l}\text { O que você } \\
\text { entende por } \\
\text { "professor"? } \\
\text { pesquisa } \\
\text { psicológica } \\
\text { sobre } \\
\text { identidade } \\
\text { profissional } \\
\text { do docente }\end{array}$ & $\begin{array}{l}\text { O artigo explora as dimensões da Identidade Profissional do Professor na } \\
\text { investigação psicológica e educacional e apresentar diferentes respostas para } \\
\text { perguntas como: que dimensões foram tidas em conta na definição de } \\
\text { professor? A imagem do professor emergente dos estudos evidencia vetores } \\
\text { de tensão entre: a) as Representações Sociais de professores e a experiência } \\
\text { cotidiana; b) diferentes percepções sobre a Identidade Profissional de } \\
\text { Professores; c) as práticas estabelecidas e a inovação no ensino; d) entre os } \\
\text { pressupostos técnicos racionalistas e as vivências dos professores, } \\
\text { envolvendo a natureza ética e emocional do ensino; e) a "realidade-tal-como- } \\
\text { ela-é" e "realidade-a-ser" no ensino. Estas questões estão intimamente ligadas } \\
\text { ao debate social alargado sobre o futuro da educação e também implica } \\
\text { questões sobre o que é um "bom" professor é, o que um professor deveria ser } \\
\text { e, consequentemente, quais são o papel e as representações sociais dos } \\
\text { professores na sociedade. }\end{array}$ & $\begin{array}{l}\text { Qual. } \\
\text { Artigo }\end{array}$ & $\begin{array}{l}\text { TATEO, } \\
\text { Luca. } 2012\end{array}$ \\
\hline $\begin{array}{l}\text { Ensaiando o } \\
\text { "novo" em } \\
\text { educação } \\
\text { física escolar: } \\
\text { a perspectiva } \\
\text { de seus atores }\end{array}$ & $\begin{array}{l}\text { Este artigo resulta de pesquisa com professores que realizam práticas } \\
\text { pedagógicas "inovadoras" na Educação Física escolar. Procura-se conhecer e } \\
\text { analisar os elementos que, na ótica desses professores, foram/estão sendo } \\
\text { importantes para a realização e sustentação dessas práticas. Os relatos dos } \\
\text { professores investigados e a posterior análise dos elementos por eles } \\
\text { apontados, por um lado, reforçam a ideia de que a compreensão da totalidade } \\
\text { desse fenômeno não pode ser efetuada sem olharmos para a complexa rede } \\
\text { de relações de fatores intra e extraescolares. Por outro, tampouco é possível } \\
\text { abordar o problema sem levar em consideração o percurso profissional do } \\
\text { professor "inovador" }\end{array}$ & $\begin{array}{l}\text { Qual. } \\
\text { Artigo }\end{array}$ & $\begin{array}{l}\text { FENSTER } \\
\text { SEIFER, } \\
\text { Paulo } \\
\text { Evaldo; } \\
\text { SILVA, } \\
\text { Marlon } \\
\text { André } \\
\text { da. } 2011 .\end{array}$ \\
\hline
\end{tabular}

Figura 1. Descrição dos 16 artigos encontrados. 


\section{Fundamentação Teórica}

O cenário educacional atual corresponde a um modelo homogêneo no qual o foco é a reprodução do conhecimento. Este fenômeno é visto notadamente em sala de aula, pois há um padrão que caracteriza a forma como o ensino acontece, através de princípios préestabelecidos que tendem a seguir de forma reprodutiva (Campolina e Martínez, 2011).

Ainda de acordo com as autoras Campolina e Martínez (2011) é neste ambiente educacional que as práticas pedagógicas reproduzem o modelo educacional vigente, validando os aspectos que corroboram com o modelo homogêneo, reproduzindo os ritmos presentes no modelo educacional vigente e predominante e desconsiderando fatores como o social e as experiências de vida.

O Brasil, na área da educação, adotou como política um padrão de processos e produtos, vinculado a um modelo de mercado competitivo e quantitativo, forçando o professor universitário a se render a esse perfil demandado pelas políticas educacionais.

Seguindo esse percusso, Silva (2011), enfatiza o problema da padronização, que se sistematiza no não reconhecimento das muitas pedagogias universitárias, que fazem parte de um contexto dinâmico e rico, que é a educação e a sociedade brasileira.

Zabalza (2004) citado por Silva (2011) reforçam a análise que se faz do cenário predominante, na atualidade, em relação a universidade no Brasil, em que se encontra presente sistemas que pradonizam, hierarquizam e fragmentam os discursos, as formações e os saberes.

No entanto, em meio a essa massificação, existem, nas universidades, movimentos de ruptura a esse padrão, sendo caracterizadas como experiências inovadoras, por se apoiarem em novos paradigmas (Silva, 2011). Santos (1989) citado por Silva (2011), explicam que essa ruptura apoiada em novos paradigmas assim o são por pautarem-se:

pela relação teoria e prática; pela construção do conhecimento baseado nos saberes prévios dos estudantes; pela instituição de práticas dialógicas e reflexivas; pelo ensino com pesquisa; pela relação 
pedagógica mais horizontalizada entre professor e aluno, ampliando o espaço, o diálogo e a aprendizagem na sala de aula (Santos, 1989; citado por Silva, 2011; p. 31).

A descrição acima, segundo Silva (2011), é a dinâmica entendida como capaz de privilegiar movimentos de práticas pedagógicas inovadoras. Essas práticas ainda não são o encontrado como regra básica, mas se apresentam em algumas instituições e sinalizam a possibilidade de uma educação cada vez mais inovadora.

No entanto, o trabalho realizado por Silva (2011), evidencia que no cenário educacional, no Brasil, já houve uma mudança, sendo identificado rupturas com o modelo tradicional, mas ainda não se configurou, essa ruptura, de forma completa, embora os primeiros passos já tenham sido dados, sendo identificados como o inicio da saída do paradigma da ciência moderna para o modelo emergente. Entretanto, a autora relata que ainda é preciso muita aprendizagem para sabermos lidar com a novidade, e assim produzir conhecimento a partir dela.

Ainda em relação a forma de ensino, Patiño Torres (2012) enfatiza que o cenário educacional de ensino superior tem muitos desafios a serem superados, uma vez que o modelo atual denuncia os empecilhos que contribuem para o avanço na educação. Segundo o autor, em sua pesquisa realizada na Colômbia, o mesmo descreve que a maioria das universidades do país, inclusive a universidade no qual fez a sua pesquisa, são pautadas principalmente em modelos clientelistas e desprovidas de preocupações a respeito das competências dos seus respectivos estudantes.

No ensino superior, ainda de acordo com Patiño Torres (2012), o processo de seleção, para ingressos nessas instituições, são, em sua maioria, baseadas em questões financeiras, aceitando os jovens a partir desse perfil, no entanto, no decorrer do tempo se o estudante não atende as necessidades da instituição, este é expurgado, ou seja, primeiro não há uma seleção adequada e depois existe um descarte. $\mathrm{O}$ interessante notar, segundo o autor, é no pequeno número de estudantes privilegiados, que chegam no ensino superior com uma subjetividade e 
formação educacional necessária para um percurso universitário de alta qualidade, pois em sua maioria, estes advem de escolas que ofertaram uma formação deficiente.

Soares e Cunha (2010) corroboram com Patiño Torres (2012), quando descrevem o ensino de nível superior, como ainda pautado em um modelo conteudista, configurando um formato homogêneo e repetitivo, onde se estabelece um clima cultural pautado no mercantilismo. Segundo os autores, para modificar este cenário é preciso fundamentalmente que seja uma mudança que faça sentido para cada pessoa [professor], levando-o a refletir sobre suas próprias práticas.

Nesse contexto educativo, citado acima, pautado por uma configuração conteudista,Carbonell (2002) explicita sete fatores, presentes nesse modelo homogêneo, que são dificultadores para a promoção da Inovação Educativa, sendo os seguintes itens: A inércia institucional; O individualismo; O corporativismo; A formação dos professores; A falta de um clima de confiança e consenso; A intensificação do trabalho docente e o controle burocrático; e a falta de suporte da administração educativa.

Sobre o tema proposto, Arruda (2014) em sua pesquisa identifica diversos fatores que são citados por ela, oriundos de pesquisas de outros autores, considerados como inibidores da expressão criativa do professor. Estes são: a dificuldade de relacionamento entre professores e alunos; a própria concepção de criatividade; a falta de tempo; a sobrecarga do currículotrabalho; as rotinas; os elevados números de estudantes; a estrutura insuficiente; a carência de recursos; a indisciplina; as dificuldades de aprendizagem; o desinteresse dos estudantes pelo estudo (conteúdo); e a ausência de apoio da direção (coordenação).

Diante de uma série de fatores inibidores, citados pelos dois autores descritos acima, que dificultam a expressão criativa do professor no contexto educativo, verifica-se que é preciso uma melhor compreensão do fenômeno estudado que dê ênfase também as possibilidades que a educação propicia para o surgimento da inovação. 
Antes de adentrarmos nas possibilidades de produção da inovação é precios entender como pensamos inovação, no qual utilizamos a descrição trazida por Campolina e Martínez (2013), que a reconhece como um processo complexo, que não pode ser sinônimo de um ato isolado. Neste contexto, a complexidade se desdobra nas mudanças que precisam ser desenvolvidas no ambiente escolar, que buscam modificar uma série de ferramentas úteis para o desenvolvimento do processo inovador na educação.

Ao se pensar na inovação pedagógica, diversos autores vão contrabalaceando os dois aspectos, o modelo tradicional e as possibilidades de inovação, para melhor clarificar o fenômeno proposto, seguindo abaixo alguns apontamentos.

Segundo Carbonell (2002) a proposta não é inovar no aspecto "material” da escola, mas sim a inovação das práticas pedagógicas; não focar nas questões administrativas, mas sim nos aspectos pedagógicos. O autor faz uma crítica ao modelo burocrático, mecanicista, repetitivo e uniforme que circunda o ambiente educacional, segundo ele o professor se vê atarefado (para cumprir questões burocráticas) e isto dificulta a produção de conteúdos econdições inovadoras.

Ainda de acordo com Carbonell (2002) a burocracia não é o único dificultador,pois existe também a falsa ideia de projetos inovadores. Segundo o autor, nem todo projeto que se qualifica como inovador o é de fato. É preciso verificar as possíveis existência de excessos idealistas, pragmáticos e fundamentalistas, que tornam o ensino formal, sem levar em conta as questões subjetivas e possivelmente torna-se um projeto permeado por um conteúdo homogêneo.

O autor citado acima considera alguns pressupostos para a efetivação da inovação educativa com base no enfoque progressivo sendo: o processo; a colaboração; a diversidade; a crítica e questionamentos; a ênfase no público; a ligação escola-comunidade; a 
complexidade; a utopia; a igualdade e a globalização. Estes são as 10 principais etapas para o enfoque progressivo da inovação educativa.

Carbonell (2002) identifica que é neste modelo progressista que o professor insere-se como ator, capaz de estimular a formação do pensamento crítico, proporcionando aos alunos a construção de respectivas identidades na hora de pensar, sentir e atuar.

As autoras Campolina e Martínez (2013), em relação a essa questão, consideram o fenômeno da inovação como presente em vários contextos da vida humana, expresso pelas práticas inovadoras do homem, estando também presente na educação, podendo ser inserida neste campo por uma diversidade de instituições e atores. Nesse contexto, a inovação, presente na área educacional pode ser uma forma de atuação das práticas realizadas por professores, coordenadores, alunos, comunidades, organizações e outros agentes da educação.

Ainda de acordo com Campolina e Martínez (2013):

$\mathrm{Na}$ instituição educacional, a inovação educativa está frequentemente relacionada às práticas pedagógicas, incluindo os processos de aprendizagem de alunos e professores, as mudanças materiais e conceituais, como programas educativos, métodos, recursos pedagógicos e currículos, e até mesmo às transformações nas formas de gestão e nas relações intepessoais entre os atores escolares (Campolina \& Martínez, 2013, p. 244).

A inovação educativa não pode ser entendida, como é confundida por vezes, com o processo de reforma e modernização tecnológica, ou seja, elementos que são planejados, na maioria das circunstâncias, fora do ambiente educacional e aí são inseridos, no entanto, não foram elementos que podem proporcionar a produção do fenômeno (Campolina \& Martínez, 2013).

Então, o que é inovação educativa? Segundo Campolina e Martínez (2013), são processos de mudança que ocorre dentro da instituição educacional, tendo seus atores envolvidos no processo, ela se cria e se constitue no próprio espaço, atendendo as necessecidades das pessoas que constituem o cenário educacional. 
Campolina (2012), responde também que a inovação educativa:

Inicialmente [...] tem sido carcterizada a partir de produtos e processos cuja qualidade do novo é significativo. O critério da novidade está em dependência do contexto em que é tomado, de tal modo que a qualidade do novo não é dada em oposição somente ao que é tradicional ou moderno, mas especificamente em função da originalidade de determinado aspecto (Campolina, 2012, p.19).

Outra autora, Silva (2011) colocam que uma maneira de tornar os processos educativos inovadores mais viáveis é pela proposta apresentada por Veiga, Resende e Fonseca (2000), em que estes evidenciam a necessidade de reformulação dos currículos de programas, programas esses que tem como objetivo a capacitação dos professores, a exemplo da formação continuada.

A proposta citada acima, segundo Silva (2011), se encontra predominante no grupo denominado força resistente, que acredita e proporciona a mudança a partir do que denominamos práticas pedagógicas inovadoras no ambiente de ensino-aprendizagem. A aula universitária, pensada a partir de práticas pedagógicas inovadoras acontecem em ambientes formais e informais e buscam romper com os modelos padronizados e estáticos, presentes em muitas instituições de ensino superior (Silva, 2011).

Lampert (2008) citado por Silva (2011) explicitam que para haver aulas inovadoras é preciso a interação entre discente e docente, e o segundo ator precisa assumir uma postura investigativa, sendo preciso que este se envolva em produção de pesquisa. Segundo Silva (2011) a produção da pesquisa auxilia no processo de ensino-aprendizagem, possibilitando que o professor não seja um mero reprodutor de verdades, mas uma pessoa capaz de produzir, juntamente com seus alunos, conhecimento. Essa construção de conhecimento, nessa proposta, se dá de maneira ativa, por ambas as partes (Silva, 2011).

Na pesquisa realizada por Silva (2011), a autora definiu alguns elementos como primordiais para a educação inovadora, elementos esses que foram encontrados em seu trabalho, sendo: a autonomia; a contextualização; a dialogicidade; a diversidade; a ética; a 
integralidade e a transitoriedade. Esses elementos, são princípios que apontam para a construção de um conhecimento crítico, contrário ao contexto padronizado e culturalmente predominante no cenário universitário.

Soares e Cunha (2010) trazem uma reflexão sobre a diferença do sistema educacional de nível superior em relação às demais instâncias de ensino. Segundo os autores, a educação superior traz as suas especificidades, e no centro destas diferenças está a condição das pessoas que permeiam este ambiente, pois tanto o docente quanto o discente se encontram na figura de pessoas adultas, e cabe ao professor compreender a importância desta relação solidária com objetivos definidos.

A partir dessa perspectiva de inovação, sendo inserido nesse contexto as mudanças de práticas, como contextualizadas pelos autores acima, é possível pensar no surgimento do professor desempenhando um trabalho pedagógico criativo. SegundoArruda (2014) trabalho pedagógico criativo significa uma prática pautada em uma criatividade que vai além da sala de aula, e que contempla os vários momentos do processo de ensino-aprendizagem, incluindo nesse contexto a própria formação do docente.

A criatividade do professor, de acordo com Arruda (2014) não se configura em um processo simplificado, mas por meio de uma trama de sistemas complexos, como o cultural, o histórico, os conteúdos atuais, sociais e individuais, que se alimentam e retroalimentam mutuamente, influenciando a prática pedagógica criativa.

A prática pedagógica criativa, de acordo com Barreto e Martínez (2007), envolve inicialmente o olhar sensível dos professores buscando o desenvolvimento de aulas que visem o melhor aprendizado dos alunos; a motivação no âmbito da teoria e prática; e também docentes capazes de ter um comportamento flexível para novas aprendizagens. Segundo as autoras, a motivação faz parte dos fatores fundamentais para o desenvolvimento de práticas inovadoras e está vinculada diretamente as questões subjetivas da própria pessoa. 
Já Tacca (2014) problematiza a prática desse suposto professor que se utiliza de diversas etratégias pedagógicas, a partir do ponto de vista interacional e dialógico. Para a autora, interação corresponde a relação social entre professor e aluno no decorrer do processo de aprendizagem que é mediado pela dialogicidade entre ambos.

Para Tacca (2014) as estratégias pedagógicas devem produzir no aluno uma emocionalidade, que o permita criar zonas de possibilidades no seu processo de aprendizagem. Segundo a autora, o sucesso das estratégias pedagógicas se evidenciam quando há uma sincronia entre o pensamento do professor e do aluno e ambos se propõe a produzir conhecimento.

Acima foram destacados diversas formas de abordar a relação do professor com os temas criatividade e inovação educativa, e esse processo investigativo, no qual propusemos realizar é uma execelente ferramenta de produção de conhecimento e uma forma de nos posicionarmos frente aos pares que já tem um percurso traçado no ramo da Inovação Educativa. Além disso, consideramos pertinente entender como o próprio professor se posiciona frente a sua prática pedagógica inovadora.

Segundo Mourao e Martínez (2006) a visão que o próprio professor tem sobre a criatividade que ele desempenha em práticas inovadoras é um importante objeto de estudo para a Psicologia. De acordo com eles a forma como o professor manifesta a criatividade está vinculada ao entendimento que ele tem de si como criativo e também a definição que este tem sobre o significado de criatividade.

Aqui nos colocamos diante de um ponto muito importante, pois acima foi dito que na atuação criativa do professor há componentes da sua produção subjetiva e também do significado compartilhado que existe sobre o tema, e esses elementos produzem uma variedade de percepções e significados sobre o concieto de criatividade, ou seja, existem 
diversos formatos de entendimentos sobre o tema criatividade, gerando, por vezes, uma confusão conceitual.

Em relação a esse fenômeno, Arruda (2014) relata que diversos pesquisadores do tema (Bolden et al. (2010); Nakano (2011); Alencar (2010); dentre outros citados por Arruda, 2014) identificaram esse conflito, pois são muitas as definições, e algumas vezes, ainda é vista por um viés do senso comum e outras vezes vinculado a objetos materiais ou instrumentais, ou mesmo como uma característica inata, defendida por alguns professores.

No tocante aos diversos conceitos de criatividade definidas pelos professores, as vezes é vista como um dom, outrora como coisa de cientista, inventores e artista, em certas ocasiões é vista como "um privilégio de poucos escolhidos" Alencar e Fleith (2003) citado por Arruda (2010, p. 33).

A criatividade que defendemos aqui é baseada na definição de González Rey (2007) que a considera como uma expressão singular subjetiva e segundo o autor ela surge em momentos de tensão, em que a pessoa rompe com um padrão pré-estabelecido e produz novas formas de compreensão e atuação sobre os fenômenos.

Sendo assim, o professor, enquanto sujeito de ação, pode se tornar produtor de criatividade e inovação, a partir da produção de sentidos subjetivos que diferem dos significados compartilhados. Sentido subjetivo, segundo González Rey (2007), é a integração do emocional e simbólico, sendo uma produção da pessoa que implica em sua subjetividade individual e também na subjetividade social.

Os sentidos subjetivos, relatados acima, na proposta de González Rey (2011) "é a unidade inseparável do simbólico e do emocional, onde a emergência de um provoca a aparição do outro sem ser a sua causa (González Rey, 2002, apud González Rey, 2011, p. 22). Segundo o autor, embora o sentido subjetivo seja produzido num contexto atual, ele não 
pode ser considerado como uma entidade isolada, pois está envolta em uma cadeia de configurações subjetivas, dentro de um processo dinâmico.

Após compreensão sobre como a teoria nos dá elementos para entendermos a produção da criatividade e inovação, iremos nos aprofundar nas especificidades desses conceitos. Primordialmente é importante entender que há uma diferenciação entre criatividade e inovação, pois segundo Martínez (1997) e Bruno Faria (2003) citado por Barreto e Martinez (2007):

A criatividade se expressa na produção de "algo" que é considerado ao mesmo tempo "novo e valioso", em um determinado campo da ação humana (Mitjáns Martínez, 1997); e a inovação uma "sequência de atividades pelas quais um novo elemento é introduzido em uma unidade social, com a intenção de beneficiar" (Bruno Faria, 2003, p.121).

A partir da definição acima de criatividade, essa pesquisa seguiu a construção da ideia citada por Martínez (2006), quando a mesma faz uma crítica ao modelo de pesquisa predominante na literatura e relata que em suas pesquisas sobre estudos relacionadas a criatividade o que chama a atenção é a tendência "de analisar a criatividade do professor a partir do que ele faz de "novo" sem, em muitas ocasiões, analisar o critério de valor, que, mesmo que extremamente relativo, constitui um dos critérios definidores da criatividade" (2006, p. 71).

Com base nessa reflexão entendemos que o estudo da criatividade proposta nesse trabalho seguiu a análise de um critério de valor, pois foram analisados profissionais com práticas pedagógicas criativas que são reconhecidas como valorosas para aprendizagem do estudante.

A criatividade no trabalho pedagógico, segundo Martínez (2006), vai além da apresentação de uma novidade e corresponde ao novo que proporciona o desenvolvimento e a aprendizagem do estudante. Segundo a autora, no trabalho pedagógico a inserção do novo, 
como processo criativo, também beneficia o professor, o seu desenvolvimento e bem-estar (emocional).

O desenvolvimento emocional do professor na produção de criatividade e inovação, trazido por Martínez (2006), é um elemento no qual consideramos relevante para a pesquisa em Inovação Educativa, pois como citado por alguns autores, o professor é peça fundamental em um processo de produção e implementação de estratégias pedagógicas inovadoras, cabendo a este participar de todo o processo, mesmo em casos em que a iniciativa não foi sua.

O professor, atualmente, encontra-se em uma situação bastante complexa, precisando refletir sobre propostas como: mudar, avançar e produzir uma nova referência do seu status profissional (Farias, 2006). Segundo a autora, esse fenômeno, que exige a mudança do professor é um movimento presente em diversas instituições da educação.

Em relação ao fenômeno da mudança educacional, é muito comum colocar o professor no posto de agente de mudança, no entanto, Farias (2006) questiona esse posicionamento, pois para ela a mudança no contexto da educação não depende de um único esforço individual. Segundo a autora, o mais adequado é considerar o "professor como um sujeito de práxis, um intelectual crítico e transformador, cuja função social exige engajamento ético e político com a emancipação dos educando" (Farias, 2006, p. 21).

Na reforma educativa a mudança na cultura docente é concebida como um processo complexo, que envolve inovação, mudança e reforma, e os professores são não os únicos, mas também atores dessa transformação necessária no contexto educacional (Farias, 2006).

Como exposto no parágrafo acima, encontramos as palavras mudança e inovação, sendo que a autora Farias (2006) assim as coloca e busca fazer uma distinção entre as duas, enfatizando que existe uma confusão conceitual entre elas, que por vezes são colocadas como 
sinônimo. Segundo a autora, trata-se de duas palavras com significados distintos, que podem ou não vir a convergir para uma mudança educacional inovadora.

A palavra mudança, descrita por Farias (2006) é um conceito importante para a reforma educativa, uma vez que na pós-modernidade o mundo vivencia esse constante processo de mudança, estando as regras do jogo sempre sofrendo mutações, e na educação o processo não é diferente, sendo pressionada a reconhecer e interagir com esse processo de mudança.

O professor é visto como um agente de mudanças, no entanto, a produção de mudança é um fenômeno complexo, no qual o professor pensa e age sobre a possibilidade de mudança, ou seja, ele reflete sobre o tempo, o desgaste, as chances de dar certo, a necessidade real da mudança, dentre outros fatores (Farias, 2006). “É essa apreciação, feita ou não de modo sistemático, que define a adesão docente à inovação, à proposta de mudança (Farias, 2006, p.72).

Já o conceito de inovação, descrito por Farias (2006), de uma maneira simplória significa a inserção de uma novidade, ou algo de novo. Segundo a autora, não se trata dizer que tal inserção seja algo inédito, mas sim um elemento novo num determinado contexto. Essa definição de Farias dialoga com as definições trazidas por Campolina e Martínez.

Sendo assim, de acordo com Farias (2006), o professor disposto a se envolver e promover a inovação pedagogia precisa muito mais do que boa vontade e compromisso, que são elementos necessários, porém não únicos ao processo de mudança a que se propõe. Para ela, um grande impasse à inovação educativa é a falta de recursos materiais e os desafios relativos as condições de trabalho.

Os professores que inovam na aula constroem um estilo próprio, resultante de um processo de constituição docente que envolve formação e autoformação, com base nas experiências vivenciadas ao longo de sua trajetória profissional e nos questionamentos que tornam possível a revisão de processos 
de ensinar, aprender, pesquisar e avaliar. São profissionais sensíveis às demandas pessoais e acadêmicas dos alunos (Silva, 2011, p. 210-211).

Nesse contexto, o professor produz uma dinâmica de aula, esta baseada na inovação, fugindo à regra da reprodução, permitindo o pensar na aquisição do conhecimento (Silva, 2011). Para Farias (2006) a prática docente é uma prática cultural, uma vez que as falas e ações dos professores estão sendo produzidas a partir de um contexto social, carregado "de significado simbólico-cultural” (p. 19). 


\section{Método}

Nessa pesquisa o método utilizado foi o Construtivo-interpretativo que está baseado na Epistemologia Qualitativa proposta por González Rey (2002) que pretende estudar ontologicamente os indivíduos concretos levando em conta a sua singularidade. Neste viés o problema é visto com base no estudo da subjetividade, compreendendo sua complexidade. De acordo com o autor fragmentar o estudo da pessoa impossibilita a percepção do todo, é em suma desconsiderar o ser complexo que é o homem.

Esse trabalho se utilizou da metodologia qualitaliva, mais especificamente dos pressupostos da Epistemologia Qualitativa, na qual descreve Silva (2011) ser um método capaz de não se limitar a dados e a forjar situações, mas sim de interagir e de se relacionar num contexto social, atuando em situações reais.

Segundo Rossato, Martins e Martínez (2014) a Epistemologia Qualitativa, é contrária ao modelo positivista que predomina na Psicologia e traz novos elementos, ou pelo menos novas discussões epistemológicas sobre os fenômenos psicológicos. Nessa epistemologia não se trabalha com dados prontos, e sim com a construção da informação, e essa foi baseada no modelo qualitativo das ciências sociais no qual propõe González Rey (2005a), que destaca ser preciso que o pesquisador seja ativo e capaz de elaborar uma construção teórica que vá além do empírico. Segundo o autor, é necessário que o pesquisador promova uma produção intelectual na qual possa oportunizar o surgimento de novas ideias.

Martínez (2014) corrobora com o autor acima, descrevendo que na Epistemologia Qualitativa quem produz o conhecimento é o pesquisador, ao contrário da pesquisa baseada no modelo positivista, no qual o dado que tem o caráter evidenciador do conhecimento. Dessa forma, segundo a autora, na Epistemologia Qualitativa é preciso que o pesquisador, ao se propor a utilizá-la mantenha uma postura criativa, ativa e reflexiva. 
A partir dos pressupostos acima, com definições sobre a Espistemologia Qualitativa discorreremos com detalhes os três princípios centrais que colaboram para o entendimento dessa proposta metodológica, sendo o caráter construtivo-interpretativo do conhecimento, a legitimação do singular e o processo de comunicação dialógico (González Rey, 2005a). De acordo com o autor, esses três princípioscontribuem para a proposta metodológica concreta, facilitando assim a compreensão do pesquisador que se propõe a utilizar esse método.

O primeiro princípio - caráter construtivo-interpretativo do conhecimento trata-se de reconhecer que o conhecimento é uma construção, ou seja, uma produção humana, não sendo considerado em hipótese alguma como algo que está pronto em algum lugar e que precisa apenas ser encontrado. Segundo o autor "o conhecimento legitima-se na sua continuidade e capacidade de gerar novas zonas de inteligibilidade acerca do que é estudado e de articular essas zonas em modelos cada vez mais úteis para a produção de novos conhecimentos” (González Rey, 2005a, p.6).

Nesse princípio, segundo Martínez (2014) o processo de produção de conhecimento é construído a partir da interpretação e hipóteses, essas, juntas, levam o pesquisador a construção de um modelo teórico.

O segundo princípio - legitimação do singular é a compreensão de que a produção intelectual do pesquisador é uma produção teórica, sendo o centro a produção de ideias (pensante) do pesquisador. Na pesquisa qualitativa, o singular tem uma grande visibilidade, pois permite a compreensão do quanto um caso ou situação singular permite a produção do conhecimento que é dinâmica e tensionadora do modelo teórico e da própria teoria no qual o pesquisador está se embasando (González Rey, 2005a).

O que é produzido em uma pesquisa, a partir da Epistemologia Qualitativa, não se resume em uma verdade, mas na capacidade de produção de inteligibilidade sobre um fenômeno, ou seja, é a construção de conhecimento sobre determinado tema, que 
denominamos modelo teórico (Martínez, 2014).Ainda de acordo com a autora o conhecimento produzido está relacionado a um momento empírico da pesquisa, no qual o pesquisador se debruça, no intuito de produzir novas zonas de sentido sobre o fenômeno estudado.

O processo de comunicação dialógico, terceiro atributo proposto por González Rey (2005), é uma importante via de construção de conhecimento. Segundo o autor, esse atributo é uma forma de conhecimento das configuraçãos e das produções de sentidos subjetivos das pessoas, possibilitando o conhecimento de diversas situações objetivas, que se constituem no social e afetam os homens.

Após compreensão dos três princípios da Epistemologia Qualitativa, é importante conhecer dois elementos importantes que constituem esse modelo de pesquisa, sendo estes os indicadores e as hipóteses. De acordo com González Rey (1997) para construção da informação é preciso a produção, por parte do pesquisador, de indicadores, sendo momentos que se constituem no empírico e que levam a produção de hipóteses, que podem ser fortalecidas.

O valor de uma informação, na Epistemologia Qualitativa, surge no momento em que o pesquisador com suas ideias e interesse de estudo se posiciona de forma ativa, criativa e reflexiva, contextualizando essa informação ao momento atual, relacionando a outras informações pertinentes ao delineamento da pesquisa (Madeira-Coelho, 2014).

Nesse trabalho, foi utilizado a estratégia metodológica do estudo de caso. O estudo de caso, segundo González Rey (2011), baseado em um modelo teórico visa a produção de conhecimento sobre o fenômeno em estudo, e neste modelo há uma via, considerada a principal, que é produtora de conhecimento, que são as configurações subjetivas, estas permitem a geração de novas zonas de sentido sobre a complexidade do singular. 
A pesquisa teve como base o conceito de "zona de sentido" que de acordo com González Rey (2005a) é uma forma de criar um conhecimento novo de significação sobre o objeto de estudo, sendo chamado essa produção de um modelo teórico, que se faz por um estudo de um fenômeno e se embasa em uma teoria que melhor representa o que está sendo investigado.

No contexto metodológico, essa pesquisa visou a produção de informações, pelo pesquisador, que proporcionou a produção de indicadores, no entanto, como ressalvam Rossato, Martins e Martínez (2014), não existem na Epistemologia Qualitativa modelos estanques, mas um processo recursivo e complexo, surgindo a importância da construção de um cenário de pesquisa, para melhor imersão do pesquisador no campo e no desempenho do seu trabalho.

Para produção da informação, neste trabalho, compreende-se ser preciso entender aspectos do fenômeno da educação, identificando esses como um processo integrado. A Epistemologia Qualitativa é vista por nós como uma proposta inovadora e segundo González Rey (1997, citado por Madeira-Coelho, 2014) ela possibilita:

\footnotetext{
A emergência de novas zonas de sentido para a compreensão da complexidade dos contextos e processos educacionais em quaisquer dos níveis, modalidades e etapas da educação e; a compreensão do fenômeno educacional como função de sujeitos históricos, culturalmente constituídos e, portanto, simultaneamente sociais e individuais, isto é, sujeitos também definidos pela complexidade de seus processos (González Rey, 1997; citado por Madeira-Coelho, 2014; p. 93).
}

\section{Instrumentos Utilizados para a Construção da Informação}

O instrumento na pesquisa qualitativa de acordo com González Rey (2002) é uma ferramenta interativa. Este pode desdobrar-se em uma infinidade de usos durante a pesquisa, indo além de uma visão objetiva, pois ao se transformarem em diversas ferramentas 
possibilitam a construção de vários instrumentos que irão permear todo o trabalho do pesquisador.

De acordo com González Rey (2002) a importância do instrumento como ferramenta interativa é a proposta da atuação do pesquisador como um sujeito ativo, que se reconheça no contexto da sua própria pesquisa e assim torna possível que o mesmo construa um sentido que o motive a desenvolver a sua pesquisa.

Nesta pesquisa foram utilizados três instrumentos que estão inseridos como características da pesquisa qualitativa:

1) Observação sistemática da prática pedagógica dos professores em sala de aula.

2) Dinâmicas Conversacionais entre a pesquisadora e os professores (Situações de diálogos).

3) Complemento de frases (Instrumento escrito) com 58 indutores.

A partir de agora, explicitaremos como cada instrumento apoiou a construção das informações na pesquisa.

1) A Observação Sistemática

A observação sistemática proposta acima como instrumento desta pesquisa foi utilizada durante a observação da atuação dos professores em sala de aula. A importância da observação surge da necessidade de visualizar as práticas, entendendo assim que somente o relato dessas práticas não é o suficiente para compreensão do processo social. Nesse contexto, a observação surge como a ferramenta adequada para compreensão da diferença do que é prática e o que ainda não se tornou prática, mas que compõe o discurso do pesquisado (Flick, 2004).

Bauer, Gaskell e Allum (2002) fundamentam que a observação sistemática é uma das possíveis ferramentas para auxiliar na construção da pesquisa qualitativa, estando esta enquadrada na geração de informações. 
A observação, por parte do pesquisador, em sala de aula, segundo Silva (2011) é fundamental, pois é nesse ambiente que a história é produzida, é nesse contexto que ocorrem as interações entre professor-aluno, mediada pelo conhecimento, sendo possível conhecer as expressões da inovação e as repercussões sociais desta, nesse espaço pedagógico.

Nas observações a pesquisadora chegou nas salas de aula um pouco antes do professor, escolheu um local da sala e ali permaneceu até o fim da aula, fazendo anotações de palavras chaves, que facilitasse relembrar de aspectos importantes para o preenchimento do Protocolo de Observação, que ocorreu depois da conclusão de cada observação.

2) Dinâmica Conversacional

O Instrumento dinâmica conversacional compreende, segundo González Rey (2011), uma forma de diálogo com base nos pressupostos da epistemologia da construção, objetivando que os participantes se envolvam em conversações, em que suas expressões não estejam limitadas a estímulos isolados. Segundo o autor, a participação do pesquisador, nesse contexto, é ativa, sendo que o mesmo pode fazer sugestões de tópicos gerais e ir acompanhando os desdobramentos da conversação.

O objetivo dessa forma de comunicação entre participante e pesquisador é a superação de expressões estereotipadas, a promoção e manutenção da espontaneidade, da refletividade e do envolvimento afetivo, esses elementos é que vão definindo a qualidade da informação (González Rey, 2011).

Sendo assim, as dinâmicas conversacionais têm por objetivo criar condições para que tanto o pesquisador quanto o pesquisado se percebam como sujeitos ativos. Neste contexto é possível a imersão em aspectos da subjetividade do pesquisado (González Rey, 2005a). Segundo o autor, esse instrumento, possibilita o processo de comunicação entre o pesquisador e pesquisado(s), sendo que é um momento em que o pesquisador deve intervir de forma 
dinâmica e criativa, acompanhando e direcionando de forma cuidadosa o momento da conversação.

Durante a dinâmica conversacional, o pesquisador deve estar atento ao conteúdo expresso pelo participante, mas também deve estar prestando atenção ao aspecto emocional da pessoa, pois essas duas formas de expressão apontam para o grau de envolvimento do pesquisado (González Rey, 2005a).

As dinâmicas conversacionais aconteceram no ambiente educacional de ensino superior em que os professores atuam e a pesquisadora deixou a cargo de ambos que escolhessem o dia e horário, considerando ser mais adequado e confortável para eles. No primeiro diálogo houve uma breve apresentação, sendo retomando ou relembrado os objetivos da pesquisa e na sequência foi pedido que o professor falasse da sua prática pedagógica.

Nos seguintes encontros, foram retomadas algumas expressões do encontro anterior e os participantes também trouxeram novas informações, no qual foram inseridas de forma “espontânea” ou, em alguns momentos, por questionamento da pesquisadora para melhor entendimento das informações trazidas por eles.

3) Complemento de Frases

Os instrumentos escritos como o complemento de frases também são instrumentos da pesquisa qualitativa, sendo considerado como uma das formas de expressões individual do participante. Em relação a esse tipo de instrumento González Rey (2005), posiciona a produção escrita como um momento em que o sujeito é capaz de escrever sobre as expressão relacionadas às produções subjetivas da pessoa no momento da pesquisa que estão relacionados ao tema proposto.

Segundo González Rey (2005a) “um dos objetivos dos instrumentos escritos é facilitar expressões do sujeito que se complementem entre si, $[. .$.$] que caracterizam as$ 
configurações subjetivas do estudado (p.51). Segundo o autor, por esta via é possível encontrar uma série de indicadores, expressos na produção do sujeito, no qual o pesquisador identifica a partir da categoria sentidos subjetivos.

Cabe ressalvar que os instrumentos de pesquisa utilizados nesse trabalho buscaram um alinhamento com a perspectiva da Psicologia Histórico-cultural e da Teoria da Subjetividade, compreendendo que "uma prática inovadora só pode ser compreendida no contexto histórico dos indivíduos" (Cunha, 1995, p. 54, citado por Silva, 2011, p.25).

No complemento de frase (Apêndice A) utilizamos 58 indutores, no qual os participantes tiveram tempo livre para completarem cada frase, tendo ocorrido com agendamento prévio.

\section{Participantes da Pesquisa}

Essa etapa foi desenvolvida a partir do desdobramento de um processo seletivo, que será detalhado no "Cenário Social da Pesquisa”, no qual foram pré-selecionados quatro casos de professores considerados criativos que trabalham em uma instituição de nível superior e atuam neste ambiente com práticas inovadoras.

A busca foi baseada por consultas/informações no próprio ambiente educacional, por alguns profissionais (coordenadores de curso de graduação) que trabalhamna instituição. O processo seletivo teve o objetivo de encontrar as características necessárias (perfil dos professores) para considerar um professor como um agente de práticas inovadoras.

Ressalvamos que no percurso do momento empírico finalizamos com dois participantes de pesquisa, sendo que descreveremos os motivos para tal número reduzido, uma vez que a intenção inicial era finalizarmos com três participantes. 


\section{Cenário Social da Pesquisa}

O cenário social da pesquisa é de muita importância para a Epistemologia Qualitativa, pois a construção desse cenário, de acordo com Rossato, Martins e Martínez (2014), compreende um processo de convivência e aproximação com os participantes da pesquisa, o suficiente para despertar nestes a confiança e interesse em participar ativamente da pesquisa.

O cenário social da pesquisa bem elaborado e dinâmico permite a produção, por parte dos participantes e do próprio pesquisador, de expressões emocionais e simbólicas, que possibilitam o conhecimento de sentidos e/ou configurações subjetivas dessas pessoas (Pires, 2014).

O nosso cenário foi constituído para acompanhar a dinâmica dos professores em sua atuação pedagógica. Após a realização da seleção dos quatro professores, foi feito um agendamento individual, respeitando a disponibilidade de horário dos mesmos, sendo um momento para apresentações pessoais e uma apresentação mais detalhada do projeto, foi também um momento para discutir a agenda (marcar as datas dos próximos encontros).

Durante todo o momento empírico a pesquisadora teve o cuidado de produzir um espaço de interação entre todos os envolvidos (pesquisadora, professores e alunos), estando sempre a disposição para o diálogo, expressando simpatia e buscando deixar todos bem à vontade para fazer mudanças, quando necessário, nas datas dos encontros ou no formato destes, sempre considerando os objetivos da pesquisa.

\section{Procedimentos Éticos}

Antes de ser iniciado a pesquisa de campo, o projeto de pesquisa foi submetido ao Comitê de Ética e Pesquisa - CEP/UniCEUB, procedimento no qual foi apresentado os seguintes documentos: Folha de Rosto Plataforma Brasil - FRPB, duas cópias do projeto de 
pesquisa, Termo de Consentimento Livre e Esclarecido - TCLE (Apêndice B) e Termo de Concordância Institucional - TCI. Após a submissão foi enviado, ao pesquisador, por email o Comprovante de Envio da Plataforma Brasil- CEPB. Depois de uma média de um mês e meio outro email foi enivado, do CEP/UniCEUB com um Informe deAprovação do Comitê de Ética - Plataforma Brasil.

Após conclusão desse processo obrigatório inicial, partimos para a pesquisa de campo, seguindo os critérios éticos e os pressupostos da Epistemologia Qualitativa.

\section{O processo de Construção da Informação}

No processo de construção da informação iniciamos com a produção de uma agenda, no qual foram colocados todos os dias no qual seriam feitos os encontros com os professores. Essa agenda contemplou uma média de seis encontros com cada profissional - dois encontros para dinâmica conversacional, um para o complemento de frases e três para observação sistemática - no entanto, não foi um processo linear, pois houveram diferenciações entre o quantitativo de observações, que foram definidas a priori entre a orientadora e pesquisadora e na sequência entre pesquisadora e professor.

Essa variação que relatamos no parágrafo acima, ocorreu em relação a observação em sala de aula e foi com respeito a momentos da pesquisa em que a pesquisadora identificou a necessidade de extender o contato com os professores, para entender melhor a dinâmica de sala de aula.

A forma de sessão de trabalho dos instrumentos ocorreu levando-se em conta a agenda de trabalho dos participantes da pesquisa, no entanto, o primeiro instrumento foi a observação sistemática, na sequência a dinâmica conversacional e por último o complemento de frases. 
Agora descreveremos o trajeto percorrido para chegarmos aos nossos participantes da pesquisa. Inicialmente decidimos que utilizaríamos os coordenadores de curso para que estes nos indicassem professores considerados criativos e inovadores.

Para chegarmos aos coordenadores dos cursos de graduação, e propormos a solicitação de indicação de professores, na instituição selecionada, seguimos algumas etapas que serão descritas abaixo:

Etapa 1 - Contato com a Instituição de Ensino.

Nessa etapa, foi agendado previamente um horário com um representante da instituição selecionada. No dia da visita agendada foi exposto as informações pertinentes sobre a proposta de pesquisa e foi solicitado o TCI. Para a confecção do TCI o representante solicitou o envio de um email com algumas informações sobre a pesquisa.

Após a visita à instituição o email com as informações solicitadas foi encaminhado e alguns dias depois o TCI foi confeccionado e entregue ao pesquisador, momento este que significou a autorização para realização da pesquisa na instituição, com a ressalva de que havíamos que esperar a aprovação do projeto de pesquisa pelo comitê de ética.

Etapa 2 - Entrevistas com os coordenadores dos cursos de graduação.

Com a aprovação do projeto de pesquisa e o TCI, foi feita uma reunião de orientação com o intuito de decisão sobre quais e quantas seriam as coordenações selecionadas para indicação de participantes para a pesquisa. Foi definido que oito coordenadores seriam convidados para a entrevista, sendo as coordenações de: Ciências da Computação; e Jogos Digitais (um coordenador para ambas); Engenharia da Computação; e Engenharia Elétrica (um coordenador para ambas); Arquitetura; Engenharia Civil; Direito; Biomedicina; Fisioterapia; e Nutrição. 
Nesssa reunião de orientação também produzimos uma ficha individual chamada: Plano de Ação para Seleção de Professores (Apêndice C). O objetivo da confecção desse material foi para fazer anotações e também para nortear a conversa com os coordenadores.

As visitas aos coordenadores foram agendadas previamente e teve uma demora média de 15 minutos, para cada uma, sendo o tema do diálogo uma breve explanação da pesquisa, a apresentação do TCI e a solicitação de indicação de professores. No momento de solicitar a indicação o pesquisador enfatizou que o perfil do participante da pesquisa corresponde a professores que desenvolvem em sua atividade pedagógica práticas criativas e inovadoras, com reconhecimento em seu contexto de trabalho.

Concluídas as oito entrevistas, havia um total de 20 professores indicados, considerados pelos coordenadores como profissionais que se adequavam ao perfil da pesquisa.

Etapa 3 - Pré-seleção dos indicados a participantes da pesquisa.

Em algumas reuniões de orientação, os 20 participantes indicados foram avaliados. O processo de avaliação teve dois critérios: 1- análise das informações descritas na ficha preenchida no dia da entrevista com o coordenador; 2 - pesquisa, feita pelo pesquisador, realizada na internet (Currículo Lattes, publicação de livros, prêmios acadêmicos, propostas criativas e inovadoras, dentre outros elementos) que visou o encontro de informações iniciais relevantes para a caracterização do perfil dos participantes. Após avaliação dos dois critérios descritos acima, foi pré-selecionado um total de sete professores.

Etapa 4 - Contato com os sete pré-selecionados:

Para contato com os pré-selecionados foi confeccionado um texto padronizado (Apêndice D) que foi enviado por email. Nesse texto constavam informações sobre o tema da pesquisa e um convite para que estes pudessem contribuir com a pesquisa, na condição de participantes da pesquisa. 
Etapa 4 - Seleção dos três participantes da pesquisa.

Dos sete pré-selecionados para a chegada aos três participantes foi usado como critério os seguintes aspectos: 1 - A resposta do email enviado a eles, na etapa três, levando em consideração o nível de interesse que os mesmos demonstraram em participar da pesquisa; 2 - Em um caso específico foi realizado uma visita para confirmação da pesquisa, pois se tratou de um coordenador entrevistado na etapa dois, que também é professor.

Etapa 5 - Contatos iniciais com os participantes da pesquisa e observações em sala de aula

Nessa etapa, resolvemos seguir com quatro professores e não três como havíamos previsto (que tinham elementos indicativos de inovação pedagógica): três que respoderam ao segundo email e o professor no qual foi feita a visita. Assim foram feitas as quatro entrevistas individuais e iniciais de apresentação e seguiu-se as observações em sala de aula, sendo três para cada professor. Durante a observação a pesquisadora fez anotações de palavras-chaves para facilitar a produção posterior do relato do caso, no diário de campo.

Com um dos professores, aconteceu uma sequencia de dois desencontros, e a aula assistida, compôs-se de uma aula caracterizada num formato tradicional, sendo: aula expositiva, no qual o professor interagiu pouco com os alunos, não havendo, a priori, sinalizadores de produção criativa. Devido a dificuldade de novos agendamentos, e tomando como base a aula assistida (observação sistemática), a pesquisadora juntamente com a orientadora, definiram seguir com os outros três participantes, e enviar por email, a este, uma mensagem de agradecimento, pela contribuição dada a pesquisa.

Ainda nessa etapa (observação sistemática), a pesquisadora, considerou interessante aumentar e incrementar as observações em sala, com um pedido, aos professores, de conversar com os alunos antes ou depois da aula observada. Diante da autorização de dois professores, a pesquisadora se aproximou dos alunos, de forma individual e se apresentou 
explicitando o interesse da pesquisa sobre a prática do professor e iniciando uma conversação informal sobre os recursos didáticos que o professor utiliza durante as aulas.

Como descrito acima, finalizamos essa etapa com os três professores, número que tínhamos definido para seguir com a pesquisa de campo.

Etapa 6 - Realização das Dinâmica Conversacionais e Complemento de Frases Com assinatura do TCLE no primeiro encontro e na sequência proposta foi realizado o complemento de frases. Nessa etapa, foram realizados três encontros com cada participante, dois para Dinâmica Conversacional e um encontro para o complemento de frases, cada uma com duração média de uma hora. Ao final desse encontro a pesquisadora agradeceu os participantes da pesquisa pela disposição e colaboração para pesquisa.

Nessa etapa (dinâmica conversacional e complemento de frases) um dos três professores não a realizou. Inicialmente, por não estar presente na instituição, pois havia feito uma viagem para um congresso internacional. Na sequência, o mesmo se encontrou enfermo, não tendo condições para estar presente nos encontros marcados e ao final, demonstrou estar com a agenda lotada, por conta do final do semestre e logo não teve tempo para disponibilizar para os devidos encontros com a pesquisadora.

Em síntese, utilizamos, para interpretação da informação, apenas as informações dos dois participantes da pesquisa que cumpriram todas as etapas do momento empírico. Assim, seguimos a nossa pesquisa com os pressupostos da EpistemologiaQualitativa (González Rey, 2002), pois não se tratou de rotular informações a partir do que encontramos no campo, e sim a compreensão de que a pesquisa é um processo aberto que possibilita a produção de conhecimentos pautados na singularidade.

Nesta perspectiva o pesquisador é considerado um sujeito ativo, pois ele consegue dar sentido as muitas experiências que o mesmo encontra na sua pesquisa. Diante dessa ideia o 
pesquisado também adquire um papel ativo, pois o mesmo é participante na construção dos significados e sentidos da pesquisa (Gonzalez Rey, 2002).

Na pesquisa qualitativa, baseado na Epistemologia Qualitativa, de acordo com o autor González Rey (2002) o estudo de caso não tem por objetivo produzir uma informação complementar, mas sim produzir conhecimento. Para o autor a pesquisa qualitativa compreende a complexidade do fenômeno que leva a criação de novas zonas de sentido do que foi estudado, que no início da pesquisa não era possível prever.

De acordo com o autor González Rey (2002) não é necessário na pesquisa qualitativa a formulação de hipóteses formais, pois o objetivo não é comprovar nem validar, mas é a construção de conhecimento. Para o autor, as hipóteses são apenas momentos que compõem o processo da pesquisa, situações em que o pesquisador pensa a respeito do "rumo" da pesquisa, no entanto, ele não se prende a estas hipóteses.

Na Epistemologia Qualitativa o conhecimento se torna um constante movimento de construção e reconstrução, assim a produção de conhecimento tem um caráter construtivointerpretativo (Gonzalez Rey, 2002). O processo construtivo-interpretativo tem assim o desafio de produzir inteligibilidade sobre o problema proposto e segue a lógica configuracional do processo construtivo dos indicadores tomando como fio condutor os objetivos da pesquisa.

O indicador é uma ferramenta de produção de inteligibilidade, que pode levar a construção de hipóteses, sendo uma ferramenta muito importante e uma ideia do próprio pesquisador, ou seja, uma produção que ocorre durante a pesquisa, no entanto, não se trata de algo pronto que se encontra em algum lugar (González Rey, 2014).

Para melhor descrição, González Rey, (2014) define o indicador como:

Uma revelação de sentido subjetivo produzida pelo pesquisador no curso das expressões da pessoas ao longo da pesquisa; o modelo teórico, porém, é o sistema hipotético em andamento que capta a integração desses sentidos subjetivos na organização mais complea das configurações subjetivas. São 
os modelos teóricos as hipóteses teóricas inter-relacionadas e em desenvolvimento que se vão organizando como produção do saber nas pesquisas e nos diagnósticos, processos que defino como geradores de inteligibilidade e não como verdades últimas, o que tem profundas implicações éticas, legais e profissionais (González Rey, 2014, p. 34-35).

A construção de indicadores iniciais, segundo González Rey (2014), levam a um enriquecimento da pesquisa, sendo mais fácil elaborar futuros indicadores, que se passariam despercebidos se os indicadores iniciais não fossem percebidos. Segundo o autor, os indicadores, organizados de forma coerente, conduzem a um momento da pesquisa em que o pesquisador terá elementos suficientes para se posicionar teoricamente.

González Rey (2014), enfatiza que para a construção de indicadores é necessário uma postura reflexiva e criativa por parte do pesquisador. Na construção da informação o objetivo proposto foi de construir indicadores e ao final, hipóteses de um modelo teórico explicativo e comparativo sobre ações e expressões referentes a prática pedagógica dos professores no desempenho das suas práticas inovadoras, discutindo e confrontando ideias com o modelo consensual encontrado na literatura utilizada como referência deste estudo.

Nesta pesquisa, os primeiros possíveis indicadores foram levantados ainda nas observações em sala de aula, no qual discutimos sobre eles durante as orientações, confrotando-os com as informações trazidas pelas literaturas que utilizamos como apoio. $\mathrm{Na}$ sequência dos encontros e a partir dos outros momentos da pesquisa de campo, alguns indicadores foram reforçados, sendo considerados bons e outros foram deixados à parte, mas não refutados, aguardando uma consolidação maior da produção de idéias dos pesquisadores.

Ao final, trabalhamos com alguns indicadores que estiveram presentes em diversos momentos da pesquisa, sendo expressões recorrentes dos participantes, ou mesmo momentos marcantes no qual eles deram informações relevantes, referentes as suas respectivas práticas pedagógicas. 
Diante do exposto seguimos para a caracterização geral dos participantes, informações produzidas a partir do cenário social da pesquisa e da utilização dos instrumentos de pesquisa, composto pela construção da informação.

A produção da informação foi feita de forma singular com cada participante selecionado, seguindo os pressupostos da Epistemologia Qualitativa. Como os casos foram analisados em particular, em respeito a nossa posição ontológica da singularidade humana e a própria história do participante. Neste caso, faremos um percurso a partir da singularidade das expressões de cada partipante, construindo indicadores e hipóteses e por fim um modelo teórico explicativo para o momento hipotético da pesquisa realizada.

Essa produção foi feita a partir das interpretações dos instrumentos e do processo do cenário social da pesquisa, entretanto, não trabalharemos por categoria de instrumentos, mas por uma via de entrelaçamento dos diversos momentos no qual foram vivenciados durante todo o momento empírico. Compreendemos que todos os encontros são importantes, sem que um se sobreponha ao outro, mas considerando-os complementares para o processo da construção e interpretação da informação. 


\section{O Processo Construtivo-interpretativo da Informação}

\section{Características Gerais do participante Mário (nome fictício)}

Com 61 anos de idade Mário é um professor universitário que atua em uma instituição de nível superior do Distrito Federal, e é professor e coordenador dos Cursos de Ciência da Computação e Jogos Digitais de uma instituição de nível superior. É professor na disciplina de: Planejamento e Gestão em TI.

O Participante é professor desde 1976, há 40 anos, deixando de exercer essa função apenas por um ano, durante todo o tempo de carreira pedagógica. Também alinhada a essa profissão o docente atua como empreendedor e como executivo de empresa. Ele também é um inventor, escritor e pesquisador, funções que desempenha em concomitância com as suas profissões de professor, empreendedor e executivo de empresa.

Em relação ao seu percurso de formação ele se graduou em Física, no ano de 1976; se tornou Mestre em Computação em 1979; e obteve seu Doutorado em Informática, no ano de 1985. Sua linha de pesquisa é em: Gestão de Tecnologia; Inovação; Governança de TI; Planejamento Estratégico e Tecnologia da Educação.

O professor criou um jogo online, no qual os alunos têm que desenvolver de forma descritiva as etapas do jogo (alimentá-lo); também busca dar aulas a partir de estudos de casos concretos, condição que segundo ele facilita a aprendizagem, uma vez que passa a fazer sentido para os alunos, dentre outros recursos pedagógicos que se alinhem a turma e ao momento da disciplina, segundo relatado por ele.

\section{Características Inovadoras no Trabalho Pedagógico de Mário: Expressões Criativas de um Professor}

Para iniciarmos a nossa produção de indicadores, destacaremos a sua habilidade para comunicar-se, buscando sempre uma linguagem simples e lógica, expressando querer sempre 
ser bem entendido e que a sua mensagem seja clara para os ouvintes que o rodeiam, expressões notadas em diversos momentos da pesquisa, desde o primeiro contato até o último encontro com a pesquisadora.

Vamos esclarecer melhor, a comunicação, tendo como significado a transmissão de informação. A comunicação é uma expressão recorrente no contexto de vida do participante. Entretanto, comunicação também é uma palavra extremamente relevante para o Método Construtivo Interpretativo, pois a disposição do participante em comunicar-se é fundamental para uma boa produção teórica e um bom processo de relação.

Ao comunicar-se o professor tem o cuidado de se fazer entendido, na primeira observação, por exemplo, o professor chega à sala de aula e como primeiro contato faz a seguinte pergunta: "Quem quer ficar rico?". Esse questionamento chama à atenção dos alunos para o professor, que repete a pergunta e começa a interagir com a turma questionando algumas respostas e impulsionando os alunos a se posicionarem frente a questão. Para os que não responderam, ele persiste: "Você não quer ficar rico?”.

E assim se segue uma aula, de outras assistidas pela pesquisadora, que foram permeadas pela busca em um processo comunicativo cada vez de mais trocas, no tocante a relação professor e aluno, momentos em que é inserido também expressões, que no agregado de suas semelhanças e repetições, denominamos um primeiro indicador de um posicionamento de modelo perante aos alunos. Em determinado momento de uma das nossas conversar, ele se expressa em relação a figura de modelo, da seguinte forma:

[...] Eu acho que eu tenho uma responsabilidade de enquanto profissional é, de uma certa forma eu tenho uma responsabilidade dupla, de executar a minha tarefa como transmissor do conhecimento, mas eu tenho também uma tarefa, aliás tripla, porque eu tenho que despertar nos alunos uma forma diferente de ver o mundo e tenho a obrigação de ser um exemplo.

O indicador acima se relaciona para nós ao primeiro objetivo específico, no qual se busca compreender as significações subjetivas que os professores produzem acerca de si 
mesmos. Nesse contexto, há informações de que a prática pedagógica do professor está intimamente relacionada as suas experiências diárias, em que as histórias pessoais e profissionais vão delineando a sua prática pedagógica, uma vez que não surge nas expressões do participante uma tentativa de segregar os diferentes papéis que ele exerce, e sim uma tentativa de relacioná-los ou melhor, agregá-los.

A sua posição de modelo, no qual ele expressa em sala de aula parte de um posicionamento deliberado, no qual ele tem a intenção de se colocar para o aluno nessa condição de modelo. Segundo ele, a proposta é que o aluno a partir dessa figura de modelo compreenda melhor a realidade, saiba que os conteúdos não são irreais, mas é parte da história de um interlocutor que fala por meio da sua própria experiência, momento em que o professor diz a pesquisadora, que esse é um elemento que faz toda a diferença para o aluno.

A sua experiência em relação ao conceito de modelo, é algo que segundo ele lhe é recorrente desde a infância, momentos no qual lembra já observar o pai e tê-lo como exemplo de vida, sendo expresso em nossas conversas e no complemento de frases, das seguintes maneiras:

Tenho um pai que, apesar de ser muito simples, [...] sabia desmontar coisas, máquinas, montar, consertar; mesmo coisas que ele não sabia como funcionava. [...] Consertar, desmontar, ou seja, ele tinha um dom pra engenharia e ele acabou contaminando, a gente diz isso quando se espelha, com essa habilidade, vontade de tentar entender como as coisas funcionam por dentro.

[...] Todos os filhos imitam os pais; [...] Porque também é um espelho; eles cresceram vendo aquilo assim como também eu cresci vendo meu pai e minha mãe e eu carrego muito da personalidade deles na minha personalidade, os meus filhos carregam muito da minha personalidade, o meu modo de ver o mundo.

10 - Meu pai meu exemplo.

16 - Minha mãe meu segundo exemplo de vida.

O conceito de modelo, no qual ele expressa com veemência, que está presente na sua vida pessoal e profissional, nos dá elementos para entendermos que se trata de uma 
configuração subjetiva, no qual González Rey (2005a) define como: “formação psicológica complexa caracterizadora da forma estável de organização individual dos sentidos subjetivos [...] (p. 21)". Essa configuração subjetiva, essa percepção de modelo, decorre de diversos sentidos subjetivos que foram se entrelaçando no decorrer do seu processo histórico, no qual são expressos nos trechos citados acima.

Consideramos ser uma configuração subjetiva pela solidez como ela se apresenta nas expressões do participante, sem confusão, sem contradições, são informações que fluem dele, com uma certa "naturalidade", não aparenta ao ouvinte ser forsoso a sua forma de apresentar a importância de ter tido um modelo e de ser um modelo, para os seus filhos e para os seus alunos. Ao falar, o participante demonstra convicção, inclusive, nesse aspecto há uma leve mudança no tom da sua voz, na expressão facial e principalmente na sua forma de olhar que se torna mais firme.

A sua expressão completa, não só a sua fala, indica ser de alguém que está convencido e confiante do que acredita ser o certo e para ele o certo é que as pessoas precisam de figuras para imitar, para ter como modelo e cabe a ele cumprir o seu papel enquanto pai e professor. Retomando os nossos teóricos e estudos, esse é ponto importante, pois ser sujeito, segundo González Rey (2005a) é ser uma pessoa consciente da experiência que vivencia, é alguém que não apenas identifica um determinado significado, mas também pensa e reflete de forma crítica sobre ele, que agrega valores e produz um sentido subjetivo sobre tal experiência.

Ora, a posição de modelo, no qual ele defende, se expressa em momentos no qual ele age em função dessa crença, e essa ação ocorre de forma consciente, sendo expresso por uma linha de expressões que evidenciam não ser somente um significado compartilhado, mas um conceito no qual ele produziu e ainda produz, procurando as melhores formas de como ser esse modelo. 
Em sala de aula o professor utiliza a sua história profissional, tanto as vitórias quanto os fracassos, como modelo a ser seguido, evidenciando aos alunos que o fracasso é parte do histórico dele e de qualquer profissional que esteja disposto a empreender e a aprender. Questionado pela pesquisadora, em um dos diálogos, sobre essa exposição da sua história para os alunos o professor diz não ter nada a esconder, mas que considera importante para os alunos ter um modelo no qual eles se expelhem, pois em algum momento eles vão lembrar dos ensinamentos e esse pode ser um impulso para que eles não desistam.

Percebemos que o professor rompe com a visão tradicional de dicotomia entre o que é público e o que é privado, o que é família e o que é trabalho, dentre outras que se assemelham as já citadas, para ele a vida é uma só e não há como segregar por espaços, tempos ou hierarquias. As experiências do passado, muitas, ainda lhe são vívidas e influenciam de forma positiva na sua forma de se relacionar com o mundo, ou seja, elas estão nas expressões atuais do participante. O futuro também é uma conexão do passado e presente, porque tem uma harmonia, ou seja, se expressam (passado, presente e futuro) como elementos que se confluem.

Nesse sentido, denominamos um segundo indicador como a flexibilidade na relação com o tempo vivido. Para o participante o tempo é importante e deve ser preenchido por planos, metas e sonhos. Sobre esses elementos, o professor expressa que:

\footnotetext{
Pessoalmente eu não tenho muitas metas, porque quando a gente chega a uma certa idade não pode colocar muitas metas não, porque não dá tempo de executar, mas eu tenho ainda um sonho [...] de um dia eu ter uma escola aonde essas preocupações, essas estratégias de ensino, não baseadas em conhecimento, mas baseadas em desenvolvimento de habilidades e competências sejam mais desenvolvidas.

5 - Infelizmente o tempo é curto.

2 - O tempo mais feliz é o tempo atual.

38 - Planejo tudo o que faço.

53 - Atualmente eu tenho muitos sonhos e vontades para realizar.
} 
A sua relação com o tempo é uma interação de uma pessoa consciente do seu percurso, um indivíduo que sabe o caminho que traçou e que embora reconheça que agora o tempo é menor, ainda sonha, planeja, sim, com certa cautela, mas acreditando nas possibilidades. Diante da sua vida, das suas escolhas e metas ele é uma pessoa que novamente se posiciona como sujeito, no qual González Rey (2005a) a descreve como uma categoria em que a pessoa se posiciona de forma ativa, criativa e reflexiva, tomando uma posição frente a determinada experiência, no qual a sua produção subjetiva se tensiona com os significados socialmente compartilhados.

Em sala de aula enquanto professor ele se expressou de diversas maneiras na qual entendemos se caracterizar também pela condição de sujeito,consciente do processo de ensino-aprendizagem e buscando diferentes estratégias pedagógicas para reafirmar a prática docente.Segundo ele, em um dos diálogos com a pesquisadora, um semestre nunca é igual ao outro, pois diz não haver ainda dado a mesma aula, mas que se atenta a turma, as experiências passadas e as reflexões feitas sobre esses momentos de outrora, o que o faz prosseguir a partir de inserção de novos elementos. Sobre esse tema ele discorre que:

Então eu tento convencer meus professores e eu mesmo a adotar essas práticas. Jogos de empresas, provocar a criação de negócios na sala de aula, dou prova com consulta; eu dou prova pra colar, tem uma hora da prova que eu deixo colar. Eu digo: "Agora vocês tem dez minutos pra colar; podem colar entre vocês. Passaram o dia fazendo colinha pequena". [...] Então a gente precisa mudar essas coisas. Então é importante a gente adotar novas práticas de ensino, não significa que vão estar certas ou erradas, mas vão mudar porque as tradicionais não estão dando certo. Vide o resultado da educação brasileira.

A expressão acima diz de um professor que reconhece que o tradicional não dá certo, mas é muito mais que isso, expressa a atitude de alguém que não tem medo de mudar e que não procura receitas prontas. É um professor reflexivo que sabe que é na relação professor e aluno que o ensino e a aprendizagem acontecem, não com uma norma estabelecida a priori, 
mas a partir das necessidade de cada um. Esse professor, tem os elementos trazidos por Silva (2011), que são: autonomia, contextualização, dialogicidade, diversidade, ética, integralidade e transitoriedade.

Na sociedade brasileira, principalmente no meio educacional, o que predomina enquanto subjetividade social é a clareza de que o modelo tradicional que não deu certo, no entanto, em vez de produzirem avanços a partir dessa constatação o que ocorre é um constante murmúrio, com expressões de insatisfação e reclamações. Mas, quantos estão dispostos a mudar? Como vemos, ao contemplar o cenário, poucos.

Podemos afirmar que são poucos os que tem a intenção de promover mudanças, pois mudar não é algo fácil, segundo Farias (2006) “toda mudança é fonte de sentimentos ambivalentes ao situar o indivíduo diante do dilema de manter o status quo ou mudar.” (Farias, 2006, p. 42).

A autora defende que mudar depende de um processo de ressignificação, salvo os casos em que não resta outra opção e há urgência da mudança, ou seja, ela se torne impositiva. Segundo ela, mudar é uma construção em que abrange os níveis individual, coletivo e interativo. Então pensemos juntos: o professor está sempre mudando a sua forma de ensinar, mas ele também provoca o aluno a produzir novas formas de aprender, essas duas informações nos fala sobre o individual e o interativo mas não para por aí ele também ele também incentiva os seus colegas de profissão a mudar, que é o seu coletivo.

Ele é uma pessoa que busca mudar e construir o mundo, a partir da sua posição crítica e a sua ação, que evidencia que não se trata apenas de sonhar, mas da concretude no qual ele produz a partir desses sonhos (idéias), esses também são elementos da mudanças, trazidos por Farias (2006). 
No entanto, Farias (2006) relata que toda inovação é sinônimo de mudança, entretanto, nem toda mudança produz inovação, e eis aqui o entrave das nossas discussões. Nesse sentido, surge a pergunta: ele é inovador e criativo?

Bom, com o descrito acima, defendemos aqui que a sua postura é de alguém que é criativo, pois ele rompe com padrões estereotipados e produz novos sentidos na sua experiência educativa. Mas ele também é inovador, quando busca elementos novos e valorosos para agregar a sua prática educacional.

Reiteiramos que enquanto professor, entendemos que ele é criativo e manifesta sua criatividade a partir da sua produção subjetiva, no qual se unem os sentidos subjetivos que ele produz e também os significados compartilhados que ele tem sobre criatividade. Essa postura é descrita por Mourão e Martínez (2006), no qual elas reconhecem ser esse um dos processos da manifestação da criatividade.

Para fortalecer nosso argumento, vemos que a sua prática criativa se alinha ao conceito trazido por González Rey (2007) no qual ele descreve que criatividade é uma produção subjetiva da pessoa, no qual ela rompe com determinado significado compartilhado e produz uma compreensão singular sobre o fenômeno.

Consideramos também que a sua prática é inovadora, pois ele introduz em sala de aula elementos novos e valiosos, no qual descrevemos como um terceiro indicador que nomeamos como versatilidade de recursos pedagógicos: jogos, seminários, conceitos, exemplos do mundo empreendedor, colocar-se na posição de exemplo, utilização de fenômenos do dia-a-dia, dentre outros. Outro recurso considerado importante é a percepção que tivemos da sua habilidade para redução de ideias. Consideramos que esse elemento se relaciona ao primeiro objetivo específico, pois se trata de ações e expressões do professor na sua prática pedagógica.

Abaixo segue expressões sobre a versatilidade de recursos pedagógicos: 
Então, na faculdade, como docente de nível superior, eu sempre busquei juntar a prática com o ensino.

[...] Então eu sempre tentei tangibilizar o conhecimento que eu estou passando em cima de casos concretos. Então minha prática didática é sempre, até hoje, sempre de trazer o mundo real para dentro da sala de aula, que é pra fazer a ponte entre a teoria que se ensina e o que aquilo significa no mundo real.[...]Então a matéria que eu ensino hoje, que é pra nível estratégico, a nível de gestão de tecnologia de informação, o livro fui eu que escrevi e ele é repleto de casos que eu vivi enquanto executivo ou consultor de empresas. Então são casos concretos, reais, que eu uso para explorar as teorias que tem que ser explicadas para quem nunca passou por isso, nunca teve em uma empresa, nunca teve que fazer planejamento estratégico de empresa.

[...] Então, a prova pra mim é mais uma aula, mas eu preciso de um processo de avaliação e pra mim não precisaria disso, mas você tem exigências legais que você é obrigado a cumprir. Então o livro é isso; no fundo é uma forma de você sistematizar o conhecimento e cristalizar. Quando você escreve um livro, aquele conceito não tem mais valor, ele já está velho. Conhecimento novo é quando eu conto um caso novo. Na sala de aula eu estou falando sobre consultorias que eu estou dando agora na empresa. Problemas que as empresas estão sentindo hoje; não as que estão no livro.

Esses recursos, nos remetem a responder a questão que Martínez (2006) escreveu “o que ele faz é valoroso?” Respondemos que sim, pois ainda na linha de raciocínio da autora consideramos valoroso para a instituição, para o corpo docente, para o próprio professor e para os alunos.

Indo mais adiante Martínez (2006) diz que a inovação também precisa proporcionar o desenvolvimento da aprendizagem do aluno e o desenvolvimento emocional do professor. Frente a esses quesitos consideramos que os recursos pedagógicos produzidos ou trazidos pelo professor podem ser facilitadores da aprendizagem dos alunos, mas queremos reconhecer que não são recursos em si que causam uma grande emocionalidade no professor, é a sua produção subjetiva sobre isso, pois desde o primeiro encontro com a pesquisadora ele deixou claro que a criatividade é essencial para o homem e a inovação educativa é fundamental para a escola, uma vez que o modelo tradicional é ineficáz. 
Retomando o primeiro contato que tivemos com o participante e devido o mesmo ser da área de tecnologia, nos preocupamos e buscamos entender o conceito que ele tinha de inovação e criatividade. Esse nossa preocupação ocorreu em decorrência do nosso cuidado inicial na hora de escolhermos o conceito de inovação e criatividade no contexto escolar que iríamos trabalhar, pois segundo Carbonell (2002) também existe o conceito de inovação relacionado a inserção de tecnologia e esse não é o nosso foco e nem a nossa posição sobre os temas, entretanto, não vamos nos alongar, uma vez que já deixamos dito qual a significação que temos sobre estes.

No entanto, identificamos, que embora ele tenha dito sobre tecnologia, tenha falado sobre doação de um computador para cada aluno, para uso em sala de aula, ter criado um jogo online, ele os considerou apenas como recursos que se adequavam a sua área de atuação (TI), mas que foram inseridos com propósitos específicos. Como relatado acima ele expressou que a criatividade e a inovação são aspectos que vão além do tecnológico, tendo haver com a forma como as pessoas se relacionam com o mundo e buscam modificá-las.

As suas expressões que nos dão suporte para compreender quais os sentidos produzidos por ele a respeito de criatividade e inovação, nos possibilitam alcançar o que está proposto no segundo objetivo específico, pois a partir dessa percepção que o professor tem ele foi traçando mudanças em seu percurso pedagógico (como descrevemos em diversos momentos) a partir dos resultados que ele foi vivenciando de suas experiências ao longo da vida pessoal e profissional.

Em um dos encontros ele fala que a mudança na forma de dar aulas ocorre na tentativa e erro, ele não tem certezas ou mesmo verdades, mas ele tem experiências passadas, que vão orientando as próximas experimentações. Em síntese, as expressões nos possibilitaram pensar que ele é alguém que está em constante produção de sentidos subjetivos a respeito das experiências e mudanças na sua prática pedagógica. 
Para finalizarmos, concluímos informando e assumindo que existe uma lacuna, pois não foi possível acompanhar o desenvolvimento de aprendizagem do aluno no decorrer do semestre, e esse foi um elemento que durante a pesquisa consideramos pertinente de ser estudado. As observações em sala de aula, foram realizadas no início do semestre, e identificamos nas expressões do professor em sala de aula a sua motivação, a sua comunicação e interesse em fazer com que os alunos obtivessem um bom desempenho de aprendizagem, mas sentimos falta de um acompanhamento mais próximo que abrangesse mais os alunos.

Essa inquientação nos levou a produzir um novo projeto de pesquisa, dessa vez com foco no aluno. Cabe ressalvar também que em relação aos objetivos dessa pesquisa atual as informações produzidas foram muitas e de qualidade, o que nos permitiu chegar a esse momento construtivo-interpretativo da pesquisa.

Com a inteção de sumarizar a produção dos indicadores sobre o participante Mário, apresentamos a síntese abaixo:

- um posicionamento de modelo perante os alunos

- a flexibilidade na relação com o tempo vivido

- versatilidade de recursos pedagógicos

\section{Características Gerais do Participante João (nome fictício)}

João tem 43 anos de idade e é um professor universitário de uma instituição de nível superior do Distrito Federal, ele trabalha nesse ambiente a 16 anos, desde o ano 2000. Nessa instituição ele atua no Curso de Engenharia de Computação, lecionando as disciplinas de: Cálculo I; Cálculo III; Métodos Matemáticos para Engenharia; Equações Diferenciais Ordinárias.Atualmente também é coordenador-adjunto, em um pólo da instituição no curso de Engenharia da Computação. 
Concomitante com essas duas atuações, professor universitário e coordenadoradjunto, o participante também, é funcionário público da Secretaria da Educação do Distrito Federal, desde o ano de 2005, quando iniciou como professor temporário e depois passou no concurso, na mesma secretaria, dando continuidade ao seu trabalho. Nessa secretaria o participante atualmente trabalha como supervisor de escola, fazendo parte do quadro de uma diretoria escolar.

Alinhando as funções de coordenação, professor e supervisor, o participante também atua como escritor, já tendo publicado livros e com alguns em andamento e outros ainda como propostas futuras.

Em relação a sua carreira acadêmica o participante é graduado em Licenciatura Plena em Matemática, tem mestrado em Matemática Pura e doutorado (não concluído) em Matemática Pura. Atualmente está elaborando um projeto para começar um novo doutorado em uma universidade federal, sendo a convite de um professor dessa instituição de ensino.

Com uma carreira profissional como professor desde o ano de 1994, fazendo no total 22 anos, o participante pretende continuar atuando na área e com planos de desenvolver melhores recursos pedagógicos para o ensino-aprendizagem em matemática, sendo que um desses recursos está em processo de produção e será o tema do doutorado que pretende iniciar.

\section{Características Inovadoras no Trabalho Pedagógico de João: Expressões Criativas de um Professor}

Dentre muitas questões João muito se difere de Mário, embora com algumas aproximações em decorrência da prática pedagógica e elementos dessa prática em que ambos compartilham dos mesmos ideiais. 
Esse participante atua enquanto professor em disciplinas que tem um teor matemático, embora ele mesmo tenha dito não se tratar de matemática pura, no entanto, o índice de rejeição e dificuldade por parte dos alunos é muito alto, segundo relatado por ele. Esses são uns dos fenômenos que tornam árduo o aprendizado de conteúdos que exigem conhecimento matemático, entretanto, existem outros, sendo sobreposto aos demais a forma errônea de ensino dessa ciência, opinião que é compartilhada e foi expressa pelo João, na citação abaixo:

Às vezes o aluno não sai muito bem em cálculo não é por causa de cálculo; é mais por causa de coisas que ele tem dúvidas, ele erra uma simplificação de frações, ele erra uma adição de frações; ele não sabe fazer o esboço de um gráfico; ele não sabe encontrar a equação de uma reta e para quem está fazendo engenharia isso é uma coisa simples.

Esse trecho da conversação foi dito a pesquisadora em um dos encontros, mas também se tem informações adiconais sobre esse tema que estiveram presentes em outros momentos de conversas informais com a pesquisadora e mesmo percebidos nas observações em sala de aula. Nas observações, por exemplo, fica claro as dúvidas que surgem em relação ao conteúdo, e são momentos em que o professor chama a atenção por se tratar de uma lacuna que deveria já ter sido preenchida nos anos anteriores, ou seja, em outros momentos da educação formal, segundo expressões abaixo.

14 - Eu ensino matemática desde 1994 e penso que posso dizer onde estão as pedras, os buracos, as
curvas fechadas e os precipícios na estrada para o aprendizado de algumas disciplinas.[...] Se eu pegar
as provas aqui e te mostrar, você vai ver que muitos dos problemas que acontecem aqui eles não estão
aqui, é o menino que não sabe fazer um cancelamento. [...] esse menino aqui, por exemplo, ele não
entendeu um conceito que eu tinha passado para ele, que é sobre regras de cadeia, ele, deixa eu ver se
acho aqui, esse não sabe derivada, nós estamos trabalhando isso aqui desde o início do curso, ele está
com deficiência, não está sabendo derivar, então, os problemas continuam acontecendo.

O participante tem uma sensibilidade para buscar entender quais são as dificuldades do aluno, ele é um profissional que está constatemente atento as debilidades encontradas em sala de aula, e promove opções para que esses alunos sejam recompensados por esta ausência 
ou deficiência de conteúdo. Isso ele o faz a partir de vídeos que ele grava, segundo relatado a pesquisadora, vídeos que ele posta na internet, sendo o conteúdo trazido pelas principais dúvidas que surgem em sala de aula e também com conteúdos que são premissas básicas para o entendimento das disciplinas lecionadas por ele.

Os vídeos são excelentes meios de comunicação, como relatado por ele, no qual diz ter muita satisfação quando os alunos informam que os vídeos o ajudaram a entender, o mesmo expressou com muito orgulho uma conversa de um de seus alunos, que disse o seguinte: "professor, eu durmo toda noite vendo você, na minha televisão lá, eu ponho para tocar lá e vou até dormir". Segundo o professor o vídeo é usado de forma consciente para que o aluno tenha mais uma ferramenta de estudo, no qual ele expressa da seguinte maneira:

[...] enfim, a estratégia que eu estou utilizando para atacar esse problema é com esses vídeos, para poder eu conseguir atingir a todo mundo sem precisar eles estarem presentes aqui. O vídeo na hora que eles puderem eles olham lá [...].Eu as vezes utilizo os vídeos que eu fiz, no youtube, eu tenho um canal, lá tem quase 600 vídeos a disposição dos meninos, então, por exemplo, eu fui dar aula ontem tinha um método lá pra gente fazer um cálculo e uma parte dos alunos não estava sabendo, não tinha visto [...] aí hoje eu mandei uma mensagem para eles, peguei uns quatro vídeos sobre isso, explicando, e aí eu pego e mando os vídeos para eles, eu consigo fazer com que a mensagem chegue para eles, sem eu ter a necessidade de marcar uma aula aqui para tratar desses assuntos.

O professor consegue compreender que existem diversos motivos que levam o aluno a “fracassar" nas disciplinas propostas, usamos esse termo quando nos referimos ao discente que não alcança uma menção (forma de avalição da instituição) suficiente para conseguir passar na disciplina. Mas por outro lado ele não age de maneira conformista, isso o afeta e produz nele certa emocionalidade, no qual ele expressa de diversas formas.

39 - Sofro [...] junto com o aluno quando eu tenho que lhe dar uma menção final abaixo de MM.

5 - Infelizmente ainda tenho um índice de reprovação que me incomoda.

1 - Eu quero saber porque os alunos têm dificuldade em aprender matemática. 
15 - Não gosto de pensar que algumas pessoas não aprendam alguns assuntos. Penso que é possível aprender de tudo. Alguns farão o percurso para o aprendizado rápido e outros não, mas todos podem fazer esta caminhada.

17 - Fico triste em ver que algumas pessoas não levam a educação a sério.

30 - Os alunos são importantes para mim. Tento fazer o melhor que posso para eles, mas as vezes não é o suficiente.

31 - Muitas vezes penso em como posso melhorar uma abordagem de um semestre para o outro. [...].

36 - Eu me sinto, olhando para o profissional um pouco frustrado por não ver o resultado do meu trabalho de forma tão evidente (boas notas, conseqüência de um aprendizado), mas todo semestre tento alguma coisa diferente. [...].

As expressões acima nos trazem ricas informações da postura de um professor que reconhece a dificuldade dos alunos, sente-se frustrado em relação a esse fenômeno, mas ele vai além da frustração. Isso nos permite elaborar um primeiro indicador que nomeamos como crença na aprendizagem e na capacidade do aluno e que está relacionado ao primeiro objetivo específico da pesquisa. Esse é um elemento importante para pensarmos que ele é um professor que rompe com o estereotipo construído e mantido na subjetividade social da educação brasileira.

Os professores, no geral, até se frustam, mas não reconhecem a capacidade de aprendizagem do aluno, colocando total culpa do fracasso no discente e assim seguindo com a consciência "limpa", pois colocar a culpa no outro é uma forma excelente de acalento para a pessoa e assim ela segue sem compreender o que está acontecendo a sua volta e sem capacidade de produzir sentidos subjetivos que a impulsionem, em momentos de tensão, para pensar novas formas de ensino-aprendizagem. Geralmente essas são pessoas com perfil similar ao mencionado por Farias (2006), mantenedoras do status quo e assim não legitimam a possibilidade de mudança no cenário educacional.

Esse professor, ao contrário do modelo citado acima, é alguém que está disposto a produzir mudanças na educação, que pensa de forma crítica e que em sala de aula assume 
uma postura de querer que os alunos aprendam e avancem (não só saber fazer, mas saber explicar o que e porque o fazem, frase dita por ele).

Nas conversas com a pesquisadora, o professor expressa o quanto almeja alcançar um maior número de alunos em sala de aula, fazer com que eles o compreendam e para isso ele traz diversos elementos, no qual denominamos de versatilidade de recursos pedagógicos, entre eles: Desenhos; História do conceito; Histórias, inventadas para as transformações dos números; GeoGebra; Diversas formas de fazer o mesmo cálculo, dentre outros.

Uma informação importante é que esses recursos não são inseridos apenas por decisão do professor, mas são pensados como elementos facilitadores do processo de ensinoaprendizagem, segundo ele relatou existem discussões com a coordenação e com seus pares sobre a inserção desses elementos, ele pesquisa as melhores ferramentas e disponibiliza tempo para dominar esses recursos.

Essa forma de inserção de recursos pedagógicos se relaciona com a descrição trazida por Campolina e Martínez (2013), segundo elas esses recursos devem ser pensados e construídos dentro do contexto escolar, visando a flexibilização do ensino-aprendizagem, sendo reconhecido pelos integrantes do processo como ferramentas úteis e cabíveis na instituição.

Essa versatilidade de recursos pedagógicos, no qual denominamos o segundo indicador, em que se relaciona ao segundo objetivo específico desta pesquisa está imbricada em um processo do qual já descrevemos um pouco nas informações descritas acima, expressa a postura de um professor que está preocupado com a aprendizagem dos alunos, mas não somente isso, ele se sente responsável pelo processo e então ele o produz de forma muito consciente, no qual podemos dizer aqui, que ele se posiciona como sujeito, que segundo González Rey ( 2005a) trata-se de uma posição ativa, criativa e reflexiva. 
O professor é consciente das debilidades do ensino, das dificuldades dos alunos e também das suas limitações, pois ele expressou para pesquisadora, em uma das conversas, que ainda precisa melhorar, pensar em ações mais estratégicas para alcançar mais alunos e reduzir o índice de reprovação das disciplinas. Nos diálogos com a pesquisadora o participante expressou de forma recorrente essa preocupação com o processo de ensinoaprendizagem, evidenciando algo que o angustia e também o deixa ansioso em relação ao futuro.

Esses dois elementos (angústia e ansiedade) estão presentes também em outras esferas da sua vida, pois ele expressou ter vivenciado muitas experiências de tensão e muitos desses momentos ainda se fazem presentes na sua vida, gerando dúvidas, questionamentos e incertezas. No entanto, é importante destacar, que esses sentimentos não o paralizaram, pois ele consegue produzir recursos subjetivos para seguir seus projetos de vida, embora, em alguns momentos da sua história o tenham feito mudar a sua rota original.

Identificamos que na sua história existem dilemas, frustrações, tristezas configurando um desejo de avançar, de fazer melhor e de mudar. Em síntese, aparece na sua expressão contradições sobre a vida, mas ele segue produzindo meios para continuar avançando, ciente da presença desses elementos e se utilizando deles, por vezes, para construir novas estratégias de mudança.

Esses recursos são produzidos também na sua vivência profissional e fica exposto objetivamente em expressões trazidas pelo participante, no qual ele vai modificando elementos do processo de ensino, por exemplo, a transformação da grade curricular para atender as necessidades dos alunos, e também a sua postura de avaliar a sua própria peformace a cada final de semestre, analisar o ritmo das turmas e pensar no que pode ser ensinado de melhor forma. 
Em uma das convesas com a pesquisadora ele mostrou as provas dos alunos rabiscadas por suas anotações (apontamentos para os alunos), ele também diz conversar com os alunos quando entrega as provas (a pesquisadora presenciou tal ação), ele dá uma segunda prova com intenção de promover melhores resultados e substituição de notas, ou seja, ele vai promovendo possibilidades para o aluno desenvolver as condições necessárias para o aprendizado.

Esses elementos, os recursos pedagógicos, utilizados por ele e aqui problematizados nos dão informações para pensarmos que esse é um professor criativo, ou seja, é uma pesssoa, que segundo González Rey (2005a), capaz de produzir uma compreensão singular a partir de uma experiência vivenciada.

Mas esses mesmos elementos também nos dizem de uma inovação educativa, pois ele busca recursos novos e valiosos, para inserir em sua prática profissional, no qual discorre nas seguintes expressoões:

e ele (o coordenador) me chamou para poder ajudar ele em algumas coisas, a gente tinha algumas idéias, algumas coisas que eu fazia com os alunos, a gente tinha até um projetinho interno, chamado matemática digital, em que a idéia era colocar os meninos para estudar cálculo com o auxílio de computador [...]. Aí a gente foi atrás, a gente trouxe para cá, hoje você pode ver que na maior parte dos computadores se você abrir aqui tem alguns programas que já são meio padrão [...] MuPAD, GeoGebra, Máxima, dentre outros [...]. São todos programas livres, os meninos podem usar os programas sem precisar pagar, a licença dele é livre, e aí a gente começou a colocar, inserir os programas de computador nas aulas, mas confesso que pedagogicamente eu ainda não senti ainda um retorno muito grande, como é que eu posso dizer? O programa é bom, é interessante, só que o aluno ele é muito mais expectador. Quando ele está numa sala de aula, os programas ajudam, a fazer com que o que eu estou falando fique mais claro $[\ldots]$.

Dentre os elementos citados acima, o que o professor mais utiliza em sala de aula, segundo ele expressou e visto pela pesquisadora nas observações, é o GeoGebra, que de acordo com ele é um recurso que otimiza o tempo, facilita a compreensão do aluno e é mais 
uma forma do discente compreender o conteúdo. É posto como uma ferramenta de apoio para a aprendizagem dos alunos (palavras do professor).

O GeoGebra foi inserido no contexto da sala de aula, por interesse do professor e com o consentimento e reconhecimento da instituição de ensino (informações trazidas pelo professor e pelo coordenador). No contato com o coordenador, o mesmo informou a pesquisadora, sobre o GeoGebra, considerando-o um recurso inovador, implementado por um professor que busca práticas criativas e inovadoras, para o ensino de uma disciplina que por vezes é posta como difícil (relato do coordenador). Sobre o GeoGebra, que se trata de um programa que produz gráficos (imagem), o professor expressa qual o objetivo na seguinte frase:

\footnotetext{
Mas enquanto a gente pode utilizar as imagens, a gente utiliza, então, os programas eles acabam auxiliando a gente nessa transmissão do recado que eu quero dar, que eu quero transmitir uma informação, aí eu falo aqui, mas essa informação tem que chegar lá no cérebro do menino, na cabeça do menino, ele tem que saber do que eu estou falando e as imagens acabam facilitando um pouco mais esse trabalho. [...] Eu poderia deixar também para ele entender isso aqui a partir do que eu falo, mas sem ver nada, mas nós somos seres humanos, somos seres que a visão é muito importante, você quando vê as coisas você aprende melhor.
}

João é um professor que tem uma percepção ampla dos processos de ensino aprendizagem, ele no decorrer das conversas e em sala de aula vai destrinchando a matemática, a partir das diversas possibilidades de aprendizagem da mesma, trazendo os recursos que citamos acima. Durante as observações, a pesquisadora ouviu cochicos dos alunos no qual eles diziam frases como "ele é o cara", "é fera demais", "nossa, ele sabe muito" e outras com mesmo conteúdo.

Essas informações expressas pelo professor e seus alunos evidenciam que a sua didádita perpassa os elementos trazidos por Tacca (2014), que são os aspectos relacionais e 
dialógicos, o professor busca uma aproximação afetiva com os alunos, no qual através do diálogo ele vai se inteirando das dificuldades e dos interesses e potenciais dos discentes.

Tacca (2014) descreve um pouco melhor seu conceito quando relata que a proposta no qual ela defende se trata de "recursos, principalmente pessoais, que implicam captar o outro, dispor-se a pensar com o outro para fazer gerar as significações de aprendizagem” (pp. 48). Vamos destacar outra expressão do professor, no qual consideramos que muito se aproxima ao dito pela autora acima.

É, eu tento ser o melhor que eu posso, o tempo que eu tenho eu tento fazer o melhor que eu posso, amanhã, por exemplo, eu tenho uma avaliação que eu marquei a tarde, para deixar os meninos fazer a primeira avaliação de novo, porque eles estavam muito verdes na época em que eles fizeram e aí acabou que muita gente não se saiu bem e agora eles estão um pouco mais maduro, minha esperança é que eles consigam fazer a primeira avaliação novamente, são outras questões, claro, mas o conteúdo é o mesmo. É uma oportunidade diferente. Então, assim, eu gosto de pensar que eu dou muita oportunidade, me dá um trabalho danado, mas tudo bem, a oportunidade está sendo oferecida. Eu pessoalmente gostaria que o resultado fosse um pouco melhor, mas ainda não é, mas a gente vai trabalhar para ser.

Aqui retomamos a discussão trazida por Tacca (2014) e concordamos com a sua postura, no qual ela afirma que os recursos pedagógicos devem ser pensados a partir de um processo de comunicação, de diálogos entre o professor e o aluno, reforçando os vínculos entre ambos, e também imbricado em uma construção dialógica que favoreça "com que as partes envolvidas façam trocas e negociem os diferentes significados do objeto de conhecimento, o que dá relevância ao papel ativo e altamente reflexivo, emocional e criativo do aluno e do professor" (Tacca, 2014, p.50).

Em suma, reconhecemos a inovação educativa, como um elemento presente na prática do professor, que muito se assemelha a concepção trazida por Campolina e Martínez (2013) no qual a inovação educativa são processos criados e constituídos no próprio espaço da instituição, que se caracteriza pela originalidade em relação ao ambiente proposto. 
É claro, que como mesmo o professor expressou ele precisa melhorar, assim como é necessário mais empenho da sua parte, mas é necessário que os alunos comecem a abandonar a postura de somente expectadores e é também importante que a instituição reconheça esses recursos inovadores e essas expressões criativas dos docentes e aqui poderíamos listar uma série de elementos que precisam mudar.

No entanto, consideramos que a postura do professor, com seu esforço intencional e deliberado, sua persistência em produzir mudanças e a sua produção pedagógica que visa a melhoria do ensino-aprendizagem são indicadores desvelados da sua atuação pautada em expressões criativas e práticas pedagógicas inovadoras.

Com a inteção de sumarizar a produção dos indicadores sobre o participante João, apresentamos a síntese abaixo:

- crença na aprendizagem e na capacidade do aluno

- versatilidade de recursos pedagógicos 


\section{Considerações Finais}

Nesse exposto, retomamos alguns conceitos que consideramos fundamentais para a implementação e continuidade da inserção de recursos pedagógicos nas instituições. No recorte do nosso trabalho o foco foi na figura do professor e assim acreditamos ser essencial o despertar da sua emocionalidade para aquilo no qual ele se propôs a realizar.

Com o objetivo de produzimos indicadores sobre como o professor subjetiva a sua criatividade no trabalho pedagógico favorecendo a prática educativa inovadora, buscamos compreender as produções subjetivas que os professores participantes desse estudo produzem acerca de si mesmos, sendo estas vivenciadas na implementação e desempenho das práticas educativas inovadoras. Como indicadores das produções subjetivas descrevemos a crença na aprendizagem e na capacidade do aluno e, um posicionamento de modelo perante os alunos como aspectos subjetivos centrais implicados da prática educativa. Além disso, em ambos os casos hipotetizamos que os recursos pessoais tem possibilitado a versatilidade de recursos pedagógicos na implementação das práticas educativas inovadoras.

Vale enfatizar que os recursos pedagógicos inovadores, nós o reconhecemos quando eles são pensados no e para o contexto escolar no qual será inserido. Entendemos que esses recursos devem ser reconhecidos pela comunidade escolar, sendo considerados por eles como elementos úteis e plausíveis de serem utilizados.

A partir das construções interpretativas do estudo, pensamos que para idealizarmos ou implantarmos recursos pedagógicos inovadores precisamos, essencialmente da comunicação entre todos os envolvidos, ou seja, no nosso contexto é preciso que haja diálogo entre o professor e o aluno, que leve à produção de vínculos que se efetivem no decorrer de todo o processo de ensino-aprendizagem.

Nesse contexto, acreditamos que a partir da emocionalidade do professor e o processo de comunicação constante entre os envolvidos é possível as trocas e negociações necessárias 
para a legitimação dos recursos pedagógicos inovadores. A partir desse pressupostos, sinalizamos ser viável um espaço educacional que proporcione no professor e no aluno uma postura ativa, reflexiva e criativa.

Para concluirmos, retomamos a discussão sobre criatividade e inovação compreendendo que ambas estiveram presentes no histórico profissional dos professores, mas que estas corresponderam a um percurso traçado a longa data e se constituíram dentro de um processo histórico, imbricado por diversas relações que foram dando sentidos as escolhas e posturas desses profissionais. Chamamos a atenção para este fato, para não cairmos na tentação de tentarmos produzir essa forma de expressão de criatividade e inovação de maneira estereotipada.

Essa pesquisa se pautou em observações do pesquisador e informações fornecidas por professores e em menor grau por alguns alunos dos docentes participantes da pesquisa. No entanto, gostaríamos de ressaltar que consideramos pertinente a continuidade da pesquisa, com mais observações e diálogos com os professores e alunos para compreendermos melhor como esses recursos inovadores e expressões criativas dos professores impactam no processo de aprendizagem de seus alunos.

Recomendamos que pesquisas envolvendo esse tema devem ser mais presentes no contexto acadêmico e ciêntifico, pois não existem muitas produções atuais sobre esse fenômeno, mas ressaltamos a contribuição de alguns autores que tem se debruçado sobre o tema e trazido informações relevantes para conhecermos melhor o cenário atual educacional de ensino superior no Brasil. 


\section{Referências}

Alencar, Eunice Maria Lima Soriano de; Fleith, Denise de Souza.( 2010). Criatividade na Educação Superior: Satores Inibidores. Avaliação (Campinas). Vol.15, n.2, pp. 201206. Disponível em: http://dx.doi.org/10.1590/S1414-40772010000200011. Acesso em: 20 de dezembro de 2015.

Alencar, Eunice M. L. Soriano de; Fleith, Denise de Souza; Boruchovitch, Evely; Borges, Clarissa Nogueira. (2015). Criatividade no Ensino Fundamental: Fatores Inibidores e Facilitadores segundo Gestores Educacionais. Psic.: Teor. e Pesq. Vol.31, n.1, pp. 105114. Acesso em: 22 de dezembro de 2015.

Anache, Alexandra Ayach; Fernandes, Vera Lúcia Penzo. (2015). Manifestações da Criatividade no Trabalho Pedagógico do Professor de Artes Visuais. Psicol. Esc. Educ. Vol.19, n.1, pp. 49-57. Acesso em: 22 de dezembro de 2015.

Arruda, Tatiana Santos.(2014). A Criatividade no Trabalho Pedagógico do Professor e o Movimento em sua Subjetividade. Tese apresentada ao Programa de Pós- Graduação em Educação da Faculdade de Educação da Universidade de Brasília/UnB.

Barreto, Maribel Oliveira; Martinez, Albertina Mitjáns. (2007). Possibilidades Criativas de Professores em Cursos de Pós-graduação Strictosensu. Estud. psicol. (Campinas). vol.24, n.4, pp. 463-473. ISSN 0103-166X.

Bauer, W. Martin; Gaskell, George; Allum, Nicholas C. (2002). Qualidade, Quantidade e Interesses do Conhecimento: Evitando Confusões. Bauer, W. Martin; Gaskell, George. Pesquisa Qualitativa com Texto, Imagem e Som: Um Manual Prático. Tradução: Guareschi, Pedrinho A. Petrópolis, RJ: Vozes.

Campolina, Luciana de Oliveira; Martínez, Albertina Mitjáns. (2011). A Escola em sua Dimensão Reprodutiva: Possibilidades e Limites da Inovação na Educação.Tunes, 
Elizabeth.(Coordenadora). Sem Escola, Sem documento. (pp.31-58) Rio de Janeiro: epapers.

Campolina, Luciana de Oliveira. (2012). Inovação Educativa e Subjetividade: A Configuração da Dimensão Histórico-Subjetiva Implicada em um Projeto Inovador.Tese de doutorado. Universidade de Brasília - UnB.

Campolina, Luciana de Oliveira; Martínez, Albertina Mitjáns. (2013). Subjetividade, Inovação e Aprendizagem. Cunha, Célio da; Sousa, José Vieira de \& Silva, Maria Abádia da. (Coordenadores). Diversidade Metodológica na Pesquisa em Educação. (pp. 241-280). Campinas: autores associados.

Carbonell, Jaume. Professorados y la Invovación Educativa. (2002). León, Pedro Cañal de. (Coordenador). La Innovación Educativa.(pp. 9-19). Ediciones Akal, S. A.

Demo, Pedro.(2010). Rupturas Urgentes em Educação. Ensaio: aval.pol.públ.Educ.Vol.18, n.69, pp. 861-871. Acesso em: 04 de janeiro de 2016.

Farias, Isabel Maria Sabino de. (2006). Inovação, Mudança e Cultura Docente. Brasília: LiberLivro.

Flick, Uwe. (2004). Observação, Etnografia e Métodos para Dados Visuais. Flick, Uwe. Uma Introdução a Pesquisa Qualitativa. (pp. 147-148). Tradução: Netz, Sandra. $2^{\mathrm{a}}$ edição. Porto Alegre: Bookman.

Faria, Bruno de Almeida; Machado, Thiago da Silva; Bracht, Valter.(2012). A inovação e o Desinvestimento Pedagógico na Educação Física Escolar: Uma Leitura a partir da Teoria do Reconhecimento Social. Motriz: rev. educ. fis. Vol.18, n.1, pp. 120-129. Acesso em: 03 de janeiro de 2016.

Fensterseifer, Paulo Evaldo; Silva, Marlon André da. (2011). Ensaiando o "Novo" em Educação Física Escolar: a Perspectiva de seus Atores. Rev. Bras. Ciênc. Esporte (Impr.). Vol.33, n.1, pp. 119-134. Acesso em: 03 de janeiro de 2016. 
Freire, Paulo. (2000). Pedagogia da Indignação: Cartas Pedagógicas e Outros Escritos. São Paulo: Editora UNESP. $2^{\circ}$ Reimpressão.

González Rey, FernandoLuis. (1997). Epsitemologíacualitativa y Subjetivdad. São Paulo: Educ.

González Rey, Fernando Luis. (2002). Pesquisa Qualitativa em Psicologia: Caminhos e Desafios / Fernando Luis Gonzáles Rey./ tradução: Marcel Aristides Ferrada Silva; revisão técnica: Fernando Luis Gonzáles Rey. São Paulo: Pioneira Thomson Learning.

González Rey, Fernando Luis. (2005a). Pesquisa Qualitativa e Subjetividade: os Processos de Construção da Informação. / Fernando González Rey / tradução: Marcel Aristides Ferrada Silva. São Paulo: Pioneira Thomson Learning.

González Rey, Fernando Luis. (2005b). Sujeito e Subjetividade: uma Aproximação Histórico Cultural/ Fernando Luis González Rey / tradução: Raquel Souza LouboGuzzo; revisão técnica do autor. São Paulo: Pioneira Thomson Learning.

González Rey, FernandoLuis. (2007). Psicoterapia, Subjetividade e Pós-Modernidade: Uma Aproximação Histórico-cultural./ Fernando Luis González Rey / tradução: Guillermo Matias Gumucio. São Paulo: Pioneira Thomson Learning.

González Rey, Fernando. (2011). Subjetividade e Saúde: Superando a Clínica da Patologia. São Paulo: Cortez.

Lima, Vivianne Bezerra Figueiredo; Alencar, Eunice M. L. Soriano de. (2014). Criatividade em Programas de Pós-graduação em Educação: Práticas Pedagógicas e Fatores Inibidores. Psico-USF. Vol.19, n.1, pp. 61-72. ISSN 1413-8271. Disponível em: http://dx.doi.org/10.1590/S1413-82712014000100007. Acesso em: 10 de dezembro de 2015.

Mariani, Maria de Fátima Magalhães; Alencar, Eunice Maria Lima Soriano de. (2005). Criatividade no Trabalho Docente Segundo Professores de História: Limites e 
Possibilidades. Psicol. Esc. Educ. (Impr.). Vol.9, n.1, pp. 27-35. Acesso em: 23 de dezembro de 2015.

Martínez, Albertina Mitjáns. (2006). Criatividade no Trabalho Pedagógico e Criatividade na Aprendizagem: Uma Relação Necessária?.Tacca, Maria Carmen Villela Rosa (organizadora). Aprendizagem e Trabalho Pedagógico. (pp. 69-84). Campinas, São Paulo: Alínea.

Mourao, Renata Fernandes e Martinez, Albertina Mitjáns. (2006). A Criatividade do Professor: a Relação entre o Sentido Subjetivo da Criatividade e a Pedagogia de Projetos. Psicol. esc. Educ. vol.10, n.2, pp. 263-272. Acesso em: 20 de agosto de 2015.

Nakano, Tatiana de Cássia. (2009). Investigando a Criatividade junto a Professores: Pesquisas Brasileiras. Psicol. Esc. Educ. (Impr.).Vol.13, n.1, pp. 45-53. Acesso em: 22 de dezembro de 2015.

Oliveira, Zélia Maria Freire de; Alencar, Eunice Maria Lima Soriano de. (2007). Criatividade na Formação e Atuação do Professor do Curso de Letras. Psicol. Esc. Educ. (Impr.). Vol.11, n.2, pp. 223-237. Disponível: http://dx.doi.org/10.1590/S141385572007000200004. Acesso em: 20 de dezembro de 2015.

Oliveira, Eny da Luz Lacerda; Alencar, Eunice Maria Lima Soriano de. (2010). Criatividade e Escola: Limites e Possibilidades Segundo Gestores e Orientadores Educacionais. Psicol. Esc. Educ. (Impr.). Vol.14, n.2, pp. 245-260. Acesso em: 24 de dezembro de 2015.

Oliveira, Edileusa Borges Porto; Alencar, Eunice Maria Lima Soriano de. (2012). Importância da Criatividade na Escola e no Trabalho Docente Segundo Coordenadores Pedagógicos. Estud. psicol. (Campinas). Vol.29, n.4, pp. 541-552. Acesso em: 24 de dezembro de 2015. 
Otaviano, Alessandra Barbosa Nunes; Alencar, Eunice Maria Lima Soriano de; Fukuda, Cláudia Cristina. (2012). Estímulo à Criatividade por Professores de Matemática e Motivação do Aluno. Psicol. Esc. Educ.Vol.16, n.1, pp. 61-69. Acesso em: 24 de dezembro de 2015.

Patiño Torres, José Fernando. (2012). Jóvenes Universitarios Contemporáneos. Contradicciones y desafios. Cali: Editorial Bonaventuriana.

Peres, Vannúzia Leal Andrade. (2014). Metodologia Qualitativa e Criatividade no Estudo da Subjetividade na família. Martínez, Albertina Mitjáns; Neubern, Maurício; Mori, Valéria D. Subjetividade Contemporânea: Discussões Epistemológicas e Metodológicas. (pp. 127-144). Campinas, SP: Editora Alínea.

Rossato, Maristela; Martins, Luiz Roberto Rodrigures; Martínez, Albertina Mitjáns. (2014). A Construção do Cenário Social da Pesquisa no Contexto da Epistemologia Qualitativa. Martínez, Albertina Mitjáns; Neubern, Maurício; Mori, Valéria D. Subjetividade Contemporânea: Discussões Epistemológicas e Metodológicas. (pp. 35-60). Campinas, SP: Editora Alínea.

Silva, Edileuza Fernandes da. (2011). Nove Aulas Inovadoras na Universidade.Campinas, SP: Papirus.

Silva, Tania Mara Tavares; Lovisolo, Hugo Rodolfo. (2011). Educação da Mente e do Corpo, Professor Pesquisador Reflexivo e a Ciência do Concreto. Rev. Bras. Ciênc. Esporte. Vol.33, n.3, pp. 605-621. Acesso em: 02 de janeiro de 2016.

Soares, Sandra Regina; Cunha, Maria Isabel da. (2010). Formação do professor a docência universitária em busca de legitimidade. Salvador: EDUFBA. Disponível em: ISBN 978-85-232-0677-2. Acesso em: 03 de janeiro de 2016. 
Tacca, Maria Carmen. (2014). Estratégias Pedagógicas. Conceituação e Desdobramentos com o foco nas Relações Professor-aluno.Tacca, Maria Carmen (Org.), Aprendizagem e Trabalho Pedagógico (pp. 45-53). $3^{\text {a }}$ edição. Campinas: Alínea.

Tateo, Luca. (2012) What do You Mean by "Teacher"? Psychological Research on Teacher Professional Identity. Psicol. Soc, vol.24, n.2, pp. 344-353. Disponível em: http://dx.doi.org/10.1590/S0102-71822012000200012. Acesso em: 03 de janeiro de 2016. 
Apêndices 


\section{Apêndice A - Complemento de Frases}

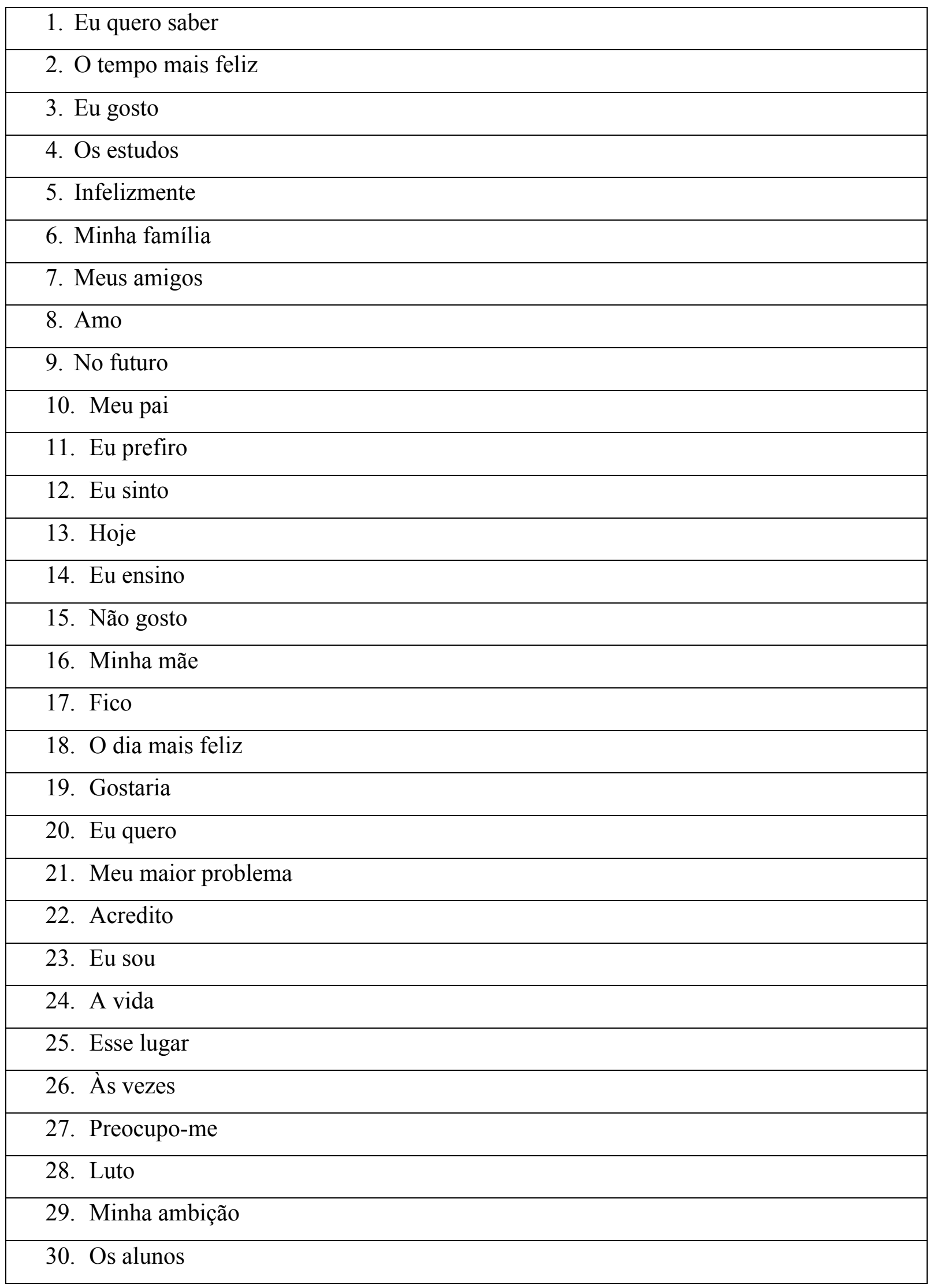




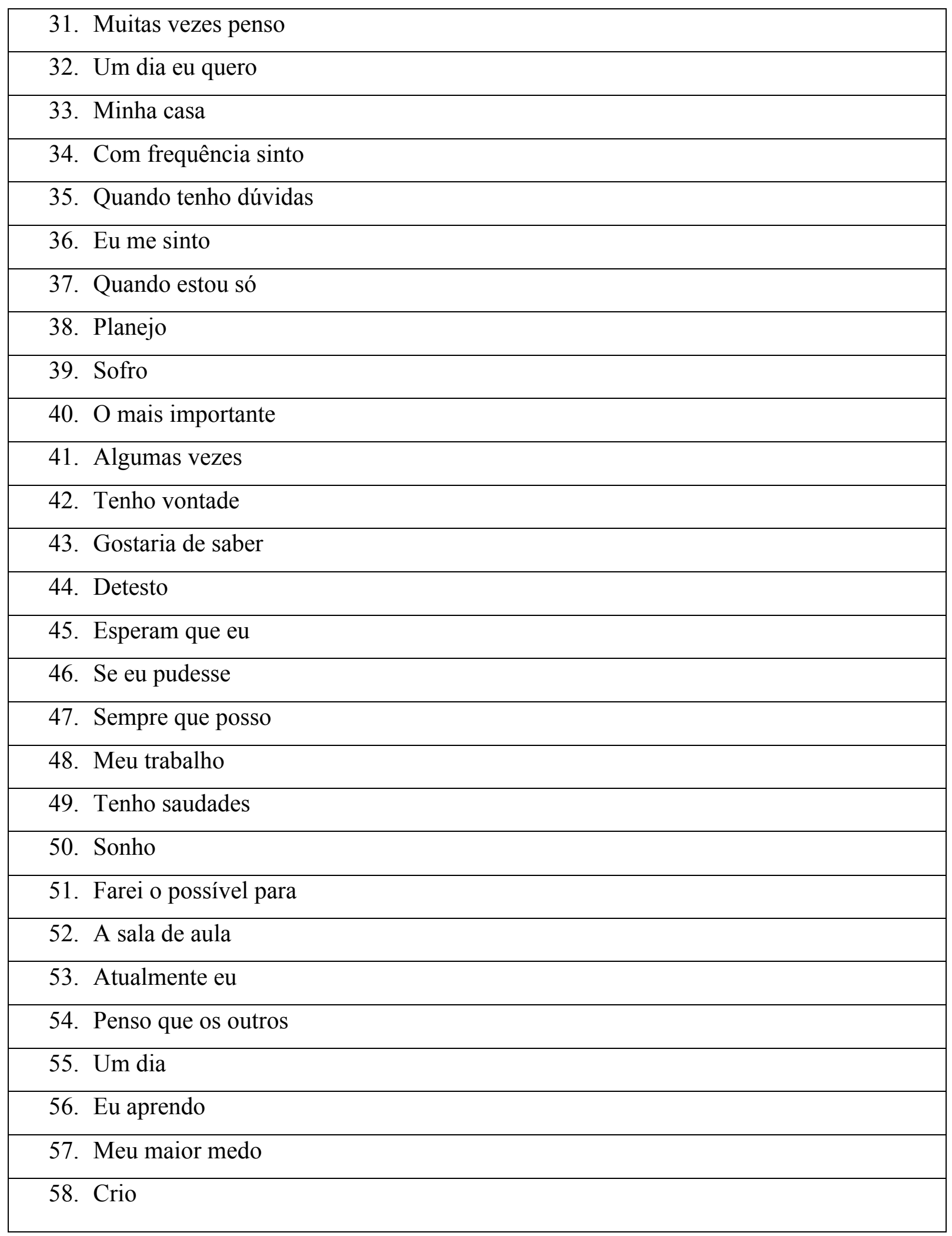




\section{Apêndice B - TCLE}

\section{TERMO DE CONSENTIMENTO LIVRE E ESCLARECIDO}

“Análise da Criatividade no Cenário Escolar e sua Expressão em Práticas Inovadoras"

Centro Universitário de Brasília-UniCEUB

FACES - Faculdade de Ciências da Educação e Saúde

Pesquisador(a) Responsável: Telma de Jesus Reis

Professor(a) Orientador(a): Dra Luciana de Oliveira Campolina

Este documento contém explicações sobre o estudo que você está sendo convidado a participar em livre e espontânea vontade. O objetivo específico deste estudo é compreender as características da sua prática docente. Sua participação consiste em contribuir com informações a respeito da sua forma de ensinar, sua relação com os alunos e com o conhecimento. O procedimento consta em observações da prática em sala de aula, na produção de redações, e no estabelecimento de sessões de diálogo com a pesquisadora. Este estudo possui "baixo risco". Caso o participante sinta a necessidade de acompanhamento psicológico durante a pesquisa, haverá possibilidade de atendimento no CENFOR (Centro de Atendimento Comunitário do UniCEUB). Sua participação é voluntária e poderá ajudar no maior conhecimento sobre as questões relativas à prática do professor e à prática educacional na universidade. Você poderá se retirar desta pesquisa a qualquer momento, bastando para isso entrar em contato com uma das pesquisadoras responsáveis. Você não receberá nenhum tipo de compensação financeira pela sua participação neste estudo. O material com as suas informações ficará guardado com a garantia de manutenção do sigilo e confidencialidade.

Caso concorde em participar do estudo, preencha os dados a seguir:

$\mathrm{Eu}$, RG

Após receber uma explicação completa dos objetivos do estudo e dos procedimentos envolvidos concordo voluntariamente em fazer parte deste estudo.

Brasília, de de

\begin{tabular}{c}
\hline Participante \\
Pesquisadora Responsável \\
Telma de Jesus Reis - email: telmajreis@gmail.com \\
Professor(a) Orientador(a) \\
Luciana de Oliveira Campolina - email: $\underline{\text { luciana.campolina@ uniceub.br }}$ \\
Teto aprovado pelo Comitê de Ética em Pesquisa do Centro Universitário de
\end{tabular}

Brasília -CEP/UniCEUB, telefone: (61) 3966-1511, e-mail comitê.bioetica@,uniceub.br . 


\section{Apêndice C - Informações para Seleção de Professores}

Plano de Ação (seleção de professores) - Ficha Individual

Nome do Professor:

Formação Acadêmica:

Área de Atuação:

Faculdade de Ensino:

Correio

Eletrônico:

Contato

Telefônico:

Indicado por:

Descrição das Características Criativas (no contexto do trabalho pedagógico):

Descrição das Práticas Inovadoras: 


\section{Apêndice D - Texto do Email Enviado aos pré-selecionados}

Prezado professor,

Eu, Telma de Jesus Reis, estudante de Psicologia do Uniceub e pesquisadora iniciante pelo CNPq (PIBIC), estou fazendo uma pesquisa sobre Educação Superior e venho através desta compartilhar do meu tema de pesquisa para fazer-lhe um convite.

Esta pesquisa tem como objetivo abordar no contexto do ensino superior, as experiências de alguns professores universitários em relação a sua prática pedagógica e história docente. Pensamos que uma pesquisa sobre esse tema interdisciplinar da psicologia e educação, apóia a produção de conhecimento sobre o ensino superior e as práticas educativas que contribuem para uma educação de qualidade.

Com a finalidade de identificar os participantes, estive pesquisando sobre professores com um perfil acadêmico interessante e produtivo a partir de informações das disciplinas do curso e currículo acadêmico. Desta primeira identificação, cheguei até o senhor e agradeço muito a atenção até o presente momento.

Considerando nosso interesse em conhecer sua prática pedagógica e sua história acadêmica, faço este primeiro contato para saber se o tema lhe interessa e se você estaria disposto a contribuir com a pesquisa dialogando um pouco sobre a sua prática pedagógica. A parte do método que se refere à pesquisa de campo consiste em algumas sessões de observação de aulas e também duas entrevistas (todas em horários e dias a partir da disponibilidade do professor).

Caso tenha interesse em contribuir com a pesquisa, solicito por gentileza, responder a esse email comentando sua disponibilidade que farei o contato novamente de modo a poder explicar mais detalhadamente a pesquisa.

Atenciosamente,

Telma Reis, Graduanda em Psicologia, pelo Ceub. 